Max-Planck-Institut für demografische Forschung

Max Planck Institute for Demographic Research

Konrad-Zuse-Strasse 1 - D-18057 Rostock · GERMANY

Tel +49 (0) 3812081 - 0; Fax +49 (0) 3812081 - 202;

http://www.demogr.mpg.de

MPIDR WORKING PAPER WP 2007-008

FEBRUARY 2007

\title{
A review of migration and fertility theory through the lens of African immigrant fertility in France
}

Anne Genereux

This working paper has been approved for release by: Gerda Ruth Neyer (neyer@ demogr.mpg.de) Deputy Head of the Laboratory of Contemporary European Fertility and Family Dynamics.

(C) Copyright is held by the authors.

Working papers of the Max Planck Institute for Demographic Research receive only limited review. Views or opinions expressed in working papers are attributable to the authors and do not necessarily reflect those of the Institute. 


\title{
A REVIEW OF MIGRATION AND FERTILITY THEORY THROUGH THE LENS OF AFRICAN IMMIGRANT FERTILITY IN FRANCE
}

\author{
ANNE GENEREUX
}

\begin{abstract}
This paper evaluates fertility and migration theory in order to further understand the impact of migration on fertility. I first analyze the fertility and migration literature separately and then look at the burgeoning literature on the impact of migration on fertility. As a result, I propose an integrated framework for analyzing the migration-fertility nexus. Within the fertility context, I use Bongaarts and Watkins concept of social interaction (1996), whereas within the migration context, I draw on Massey's capitalist transition theory (1999), and Pessar and Mahler's 'gendered geometries of power' (2003). This integrated framework considers three major factors: the sending country, the global context of migration systems, and the receiving country. Gender is the key to understanding fertility decisions within all three levels. Migration from Africa to France is considered in order to exemplify these processes. Bozon's typology of African demographic patterns (2001) shows how and why the sending country matters for future childbearing decisions post-migration. To further explore this facet, four countries are used to evaluate the impact of migrating from specific types of countries on fertility post-migration: Senegal, Mali, Cameroon, and Rwanda. The global context of migration is constantly changing, both encouraging and restraining men and women in particular ways, which also affects fertility choices. Finally, the receiving country interacts with migrants in various ways-immigration policies, the economy, and social institutions-playing important roles in fertility outcomes.
\end{abstract}




\section{INTRODUCTION}

II. THEORETICAL BACKGROUND
A. Fertility
B. Migration
C. Gender and Migration
D. Migration - Fertility Hypotheses
E. Bringing it Back Together
Country of Origin
Global Context of Migration Systems
Receiving Country

\section{F. Conclusion}

III. Fertility IN AfricA
A. Explaining African Fertility
B. Education and Residence
C. Rural-Urban Migration and Fertility
D. Demographic Patterns in Africa
E. Cases
Mali
Senegal
Cameroon
Rwanda

F. Conclusion

IV. Global Migration Patterns
A. African Migration
B. Migration from Mali, Senegal, Cameroon, Rwanda
C. Africa, Gender and Migration
D. African Migration to France
E. Conclusion

V. CONTEXTUAL FACTORS IMPACTING AFRICAN IMMIGRANT FERTILITY IN FRANCE
A. Immigration Policies
B. Economic Factors
C. Interaction with Social Institutions
D. Changing Gender Norms
E. Malians, Senegalese, Cameroonians and Rwandans in France

VI. CONCLUSION AND OUTLOOK 


\section{INTRODUCTION}

In July 2006, France's interior minister, Nicolas Sarkozy, succeeded in passing new immigration and integration laws that will allow the government more control over migration. These laws restrict immigration significantly, moving from a policy of family reunification to selective employment immigration. These policy changes are the culmination of increasing migration from southern countries, rising unemployment in France, and significant problems of integration and social unrest as demonstrated by the rioting of first and second generation African immigrant youth in the Paris suburbs fall 2005. These tensions and restrictions epitomize the current state of migration globally.

African migration has increased significantly in the last 20 years, including migration to France. In addition to legal migration, it is estimated that currently there are 200,000-400,000 unauthorized immigrants in France. Thus, how the population of Africans in France can be expected to change in future years is a matter of great concern. Since both migration and fertility contribute to population growth, just how these two demographic trends intersect for the AfricanFrench population is a critical consideration. The competition for jobs and access to social services has strained relations between native French and immigrants. This tension is partially seen in the public discourse on African 'uncontrolled fertility.'

Africa remains the highest fertility region in the world while France as a part of Europe is in one of the lowest. Thus, African immigrants are moving between and contributing to two very different fertility regimes, where the term fertility regime refers to the multiple and interacting local, national, and international social factors that give rise to particular fertility patterns. Africa is experiencing unprecedented migration levels and Africans are moving to countries with lower fertility rates. This migration has the potential to change both the population dynamics in sending countries as well as receiving countries. In fact, some argue that migration is the catalyst for a third demographic transition (Coleman 2006). France is one of the major receiving countries of African immigrants. As a result of labor migrations stemming from colonial history, there is a wide range of migration experiences in terms of when, how and why Africans migrate to France and their subsequent marriage and fertility decisions.

Although sub-Saharan immigrant fertility in France is significantly lower than fertility in sub-Saharan Africa (2.86 verses 5.5) (Bozon, Lelievre et al. 2001; Toulemon 2004), these rates alone say little about the processes involved in the different life trajectories of migrant women in 
comparison to non-migrant women. What fertility-related factors influence the decision to migrate and/or to remain in France? How are family regimes of both the sending and receiving countries gendered, and how do they affect the intersection of fertility and migration? What factors most influence sub-Saharan immigrant women's fertility decisions once they are in France?

In this paper, I argue that an integrated model of fertility and migration would better consider the diversity of African sending contexts and gender related issues, thus producing a more coherent understanding of the impact of migration on fertility. In the first section of this paper, I review the general theoretical literature on fertility and migration, with emphasis on the gendered component of each. Then I summarize the major migration-fertility hypotheses. To conclude the first section, I present an integrated framework for researching the impact of migration on fertility. In the second section, I use this framework to examine the sending country context. I review general data on African fertility and migration, and introduce Bozon's demographic typology of Africa. This typology emphasizes the vastly different contexts from which Africans migrate, and as a result can help clarify what fertility changes in France can be expected and how those changes will occur. Consequently, I use Bozon's typology to choose four countries, each representing one demographic pattern: the traditional (Mali), classical (Senegal), AIDS perturbed (Cameroon) and war-perturbed (Rwanda). I compare national development indicators, gender norms, national reproductive health programs and the indirect and direct determinants of fertility as well as other local fertility considerations. Before turning to the receiving country, I present the Africa-France migration stream within the global context. In the third section, I turn my attention to the receiving country, France, highlighting the major contextual factors that affect immigrant women's childbearing decisions. 


\section{THEORETICAL BACKGROUND}

This paper unifies two areas of research which have primarily been studied separately, fertility and migration, and adds a dimension that is sometimes surprisingly ignored, gender. Therefore, I first review the theoretical literature on both fertility and migration, highlighting how and why gender is pivotal to understanding both phenomena. Then, I will present the major hypotheses scholars have proposed to explain how migration impacts fertility in general, as the context for considering how these may or may not apply to understand the African-French case.

\section{A. Fertility}

On a global level, demographers talk about the first and second demographic transitions, ideas that today are the base of reference for explaining fertility despite the criticisms that have sometimes been leveled at them. The first demographic transition is associated with modernization and economic development in the wake of the industrial revolution. Based on a description of the fertility decline in Europe, it was argued that modernization improved health conditions and lowered mortality, eventually leading to lower fertility rates through a change in fertility norms. The claim that this same process describes fertility decline universally has been highly criticized for ignoring contextual factors (De Bruijn 2006). It does, however, describe the broad effects, but it cannot predict fertility transition and is seen as too unilinear and irreversible (Notestein 1945). In fact, Coale (1973) showed that socioeconomic indicators of modernization did not account for the timing of fertility transition in Europe. Despite these faults, there is little doubt that industrialization has had an enormous impact on fertility. Industrialization changed the modes of production and consumption from household-centered and patriarchially-controlled to individualized markets for labor and goods, which had far-reaching effects on marriage, gender and reproductive norms (Boserup 1970).

Lesthaeghe and van de Kaa (1986) coined the term second demographic transition which they defined as fertility decline below replacement level, contraceptive use, postponement of marriage and parenthood as well as increased cohabitation and individualism. Generally, the second demographic transition is explained as resulting from a broad change in values in combination with historical forces such as increased access to birth control, and gendered changes in labor markets that change men's opportunities and foster women's economic 
independence. Women's economic independence also reflects changes in patriarchal values and practices in the home, which indicate cultural and ideological change. ${ }^{1}$ Both the first and second demographic transitions describe phenomena that have occurred in the most developed countries of the world. Both transitions occurred in response to major economic and social changes and these changes occurred in concert with major changes in gender relations.

Demographers have offered more detailed explanations for these fertility transitions in several non-exclusive theories which include economic and non-economic factors (Lesthaeghe and Moors 2000). Emphasizing economics, the classic demographic ${ }^{2}$, neoclassical ${ }^{3}$, and relative deprivation theories claim that individual and household socio-economic status, the increased cost of raising children and increased consumer desires drive fertility decline. These economic changes are embedded within a structure of urbanism, modernization and capitalism. An important part of "modernization" is cultural, which is linked to increased education, particularly for women. Increased female education "leads to female participation in the workforce, female economic autonomy, higher costs of entry into a union, higher opportunity costs associated with childbearing and childrearing and to greater assertiveness in favor of more symmetrical gender roles" (Lesthaeghe and Moors 2000).

Scholars have challenged this primarily economic assessment of fertility decline, showing that at the macro-economic level development does not predict fertility transitions and

\footnotetext{
${ }^{1}$ Other work by Lesthaeghe (1983) pushes the economic modernization models by underlining the importance of the shift in values towards individualism and self-fulfillment that occurs with rising affluence and secularization. His model works particularly well for Europe but not other regions. In a similar vein, Cleland and Wilson (1987) argue that fertility change has both cultural and economic explanations, referred to as ideational theory. They argue that changing norms and increased individualism play important roles in fertility behavior change and that diffusion of information and social norms about birth control lead to fertility decline. Ideational theory does not work well at explaining fertility in Africa.

${ }^{2}$ Classic demographic theory relates fertility decline to increased socioeconomic status and the fall in mortality rates which accompany industrialization and urbanization (Thompson 1929). Notestein (1953) theorized that as society modernizes, economic and social changes such as industrialization, urbanization, development of technology, increased education, and decline in mortality lead to a subsequent decline in fertility. Traditional society is replaced with a secular, individualist society. The rising costs and declining economic value of children are the driving forces of fertility change.

${ }^{3}$ Neoclassical microeconomic theory primarily associated with Becker also uses an economic paradigm for explaining fertility decline; this theory argues that couples examine the relative cost of having children versus competing forms of consumption. In this model, higher costs of marriage, childbearing and childrearing lead to lower fertility rates. Easterlin (1975) only modifies slightly neoclassical theories by emphasizing the supply of children and the costs of birth control; the higher the costs the less consequential fertility desires become because the costs are prohibitive.
} 
decline (Coale 1973; Watkins 1987; Bongaarts and Watkins 1996) ${ }^{4}$. Generally, the more economically developed a country is, the lower the fertility rates are. However, the Human Development Index (HDI) was created by UNDP, as a measure of development calculated using a linear combination of life expectancy, literacy and real GDP per capita variables, fails to predict fertility transition (Bongaarts and Watkins 1996). There is no tight link between development indicators and fertility in a single historical period. Though no linear relation has been shown between fertility and development, the overall negative correlation does include some non-linear regularity.

To explain the non-linear pattern of fertility decline, Bongaarts and Watkins (1996) propose the idea of social interaction. ${ }^{5}$ Social interactions regulate the process of fertility transition through: 1) the exchange of information and ideas; 2) the joint evaluation within the local context; and 3) the social influences that constrain or encourage action. These social interactions operate at local, national and global levels. The social interactions of exchange, evaluation and social influence overlap and are mediated through conversations, observation, inference, media, forums, governments, and NGOs. The extent of a country's participation in a global society is relevant for the timing of its fertility transition. International migration is one example of a country's participation in global society. The argument is that the extent to which a country is integrated into the global economy (or conversely, how isolated it is) will affect

\footnotetext{
${ }^{4}$ Coale (1973) explored the prerequisites for fertility decline and showed that indicators of economic modernization and fertility transition are inconsistently correlated discrediting modernization theories of fertility decline. As a result, he identified three preconditions for fertility decline: 1 . fertility must be in the realm of conscious choice; 2 . there are known methods and access to contraception; and 3. limitation of fertility must been seen as an advantage. Coale and Watkins (1985) tested Notestein's theory within Europe and concluded that socioeconomic status only weakly predictive of fertility declines and fertility transitions started at widely varying levels of development. He showed that once marital fertility in one region in a country had begun to decline, neighboring regions with same language or culture followed after short delays.

Lesthaeghe and Moors (2000) review of fertility and family formation; though focused on industrialized countries their review brings to the fore important issues for fertility change that have been less emphasized yet significant in the case of the impact of migration on fertility. They show that industrialized countries, all of which have considered to have gone through the second demographic transition, have taken different paths to get there. They show this by analyzing the recuperation and household formation patterns. For example, some countries may have experienced similar declines in fertility but the average age of first childbirth can be significantly different. ${ }^{5}$ Bongaarts and Watkins (1996) show that in pretransitional societies fertility differs with the main determinants of fertility being age at marriage and breastfeeding, both of which are under social control. Further, they show that there is a correlation between the rapidity of fertility decline and the level of development at the moment of transition. If a country enters fertility transition at low levels of development, fertility decline occurs more slowly than countries which enter the transition when more developed. High unmet need for contraception and high levels of development lead to rapid fertility decline. Regions have leaders and followers. Populations undergo fertility transition earlier than neighbors because structural changes and through diffusion, others undergo transition before experience structural changes similar to lead country.
} 
fertility patterns by changing interactive communication of fertility norms. Bongaarts and Watkins (1996) contend that individuals do not make childbearing decisions in isolation, so social interaction will either inhibit change in fertility norms and behaviors or accelerate the pace of transition.

Supporting Bongaarts and Watkins, Casterline (2001) replaces the term social interaction with social effects ${ }^{6}$ and places additional emphasis on the relationship between economic aspirations and expectations as the critical factors in determining the pace of fertility change. Caldwell and Caldwell $(1987 ; 2002)$ address those factors that constrain fertility change, particularly cultural constraints such as the economic value of children, child fostering, polygamy and land inheritance norms, which play important roles in African fertility. Lesthaeghe and Moors (2000), in their review of fertility transition research, conclude that specific patterns of diffusion, government policies, economic hardship, and cultural traits are central to understanding fertility, meaning that the characteristics of the health care, education and social welfare systems, the economy, and family as well as lifestyle norms are all factors that contribute to fertility rates.

The various economic and social explanations of fertility behavior are linked to both direct and indirect determinants of fertility. The indirect determinants are considerations such as the economy, education of women, and residence while direct determinants of fertility are those factors such as use of contraception, the proportion of women married or in sexual unions (exposure); frequency of intercourse; postpartum abstinence; lactational amenorrhea; induced abortion; spontaneous intrauterine mortality, natural sterility; and pathological sterility (Bongaarts, Frank et al. 1984). The impact of patterns of marriage and sexual unions and of sexual activity on fertility is of particular interest due to their complexity and culturally based understandings/ rules/ norms.

Marriage and sexual unions influence fertility through: type of marriage (monogamous, polygamous); age at first marriage; proportion of women who never marry; frequency of divorce,

\footnotetext{
${ }^{6}$ Social effects are similar to what Bongaarts and Watkins (1996) call social interaction, which includes social learning, social influence and social norms. Social effects impact fertility through economic factors such as the costs of contraception, fertility desires, perceptions of mortality conditions, evaluation of costs and benefits of schooling, and desires for consumer goods. For Casterline, the key determinants of the pace of fertility decline include: a. pace of soc and econ change; b. pace of change in economic aspirations; c. pace of improvement in provision of birth control services and d. pace of reduction in moral and social costs of birth control. Social effects are more efficacious under certain patterns of social relations than others. By this he means that certain patterns of social integration, i.e. weak or tight network ties can encourage or discourage fertility transition.
} 
widowhood and remarriage; and patterns of sexual activity, which vary according to marriage form and habitation patterns, particularly in countries where spousal separation is common. It is through these proximate determinants that the indirect background factors affect fertility.

Though women's education and employment figure in many accounts of indirect determinants of fertility decline, gender has not been prominently discussed in mainstream demographic literature, Mason (1997) reviews the literature that addresses the place of gender in demographic change. She explains both why gender is important, but also why it is difficult to incorporate analysis of gender into models of demographic change. As gender is socially constructed, gender regimes include expectations of male and female behavior. These expectations are enforced informally and formally by the state, community, kin, and friends. Gender regimes manifest themselves most obviously in the division of labor and unequal power relations. Demographic transition theories are implicitly based on the improvement of women's status from one economic regime to another ${ }^{7}$. However, the variation in how gender systems work is not linear, irreversible or economically determined. Gender is socially constructed and politically contested; it reflects particular societies and communities at particular historical moments.

Some researchers have explored these contingent gender dynamics, particularly in relation to fertility decision-making. U.S. research shows that husbands' desires and intentions do impact whether their wives give birth (Thomson 1997). Further, when couples disagree about having another child both partner's intentions shift to not having a child. Thomson (1997) concluded that these patterns were the same for both traditional and egalitarian couples. Yet research on couples in Africa show that gender power relations are seen in fertility decisions. Ethnographic research by Amy Kaler shows the 'everyday' struggles for power between genders and generations regarding fertility (Kaler 2000; Kaler 2003). She argues that conflict, resistance and subversion define fertility regulation in Zimbabwe, where women's ability to control their own fertility was seen as threatening the gender hierarchy. Because it is about such power struggles, fertility regulation needs to be seen not only at aggregate levels but also at the

\footnotetext{
${ }^{7}$ McDonald (2000)argues that in developed countries gender equality in individual-oriented institutions has improved dramatically as seen in women's education and employment. This improvement has lead to fertility transition from high to low levels. However, he argues that gender equity within the family has been slower and that this inequality limits the number of children women bear actually inhibits their realization of desired childbearing.
} 
individual, family and community levels where these contests may have different outcomes. ${ }^{8}$ The temporary effects of policy interventions, Lesthaeghe and Moors (2000) argue prove that economic, social and ideational forces are most pertinent.

These theories provide tools for addressing African fertility more specifically. Here too, economic development plays an important role in fertility change but insufficiently explains variations in timing of fertility transition onset. I argue that examination of various social interactions at the local, national and global levels will help to understand fertility transitions (and/or continuities) both in Africa and in the African Diaspora. Gender also plays out on these various levels and is closely linked to fertility, particularly the organization of labor and access to resources through wage employment. Bongaarts and Watkins' social interaction perspective with its emphasis on local, national and global levels implicitly includes gender and will help frame the problematic of migration and fertility (1996).

\section{B. Migration}

As with the literature on fertility, there is no coherent theory of international migration, nor is there an agreement on the ways in which migration is a gendered process. Migration theories are primarily economic in nature, yet work on different levels of analysis -- the individual, household, national and transnational -- and thus result in identifying different explanatory mechanisms and implications for policy. ${ }^{9}$ A neoclassical understanding of migration is a classic push-pull model in which wage and employment differentials are essential, that migration is about supply and demand with rational actors trying to maximize their income. The new economics of migration challenges this view by focusing on how families use migration as a strategy to minimize risk, diversify income sources and ultimately provide for larger units of related people. Dual systems theory focuses more on the pull or demand side; 'immigrants fill a demand for labor that is structurally built into modern, post-industrial economies and influencing this demand requires major changes in economic organization' (Massey 1993: 444). World systems theory sees immigration as a natural consequence of economic globalization and market penetration across national boundaries. Douglas Massey (1999), using world systems theory, proposes a "capitalist transition" theory: "contemporary immigration flows originate in the

\footnotetext{
${ }^{8}$ See Ginsburg and Rapp (1991) for more regarding reproduction as a contested domain.

${ }^{9}$ For more detail regarding these theories see: (Massey 1993)
} 
social, economic, political and cultural transformations that accompany the penetration of capitalist markets into nonmarket or premarket societies (as hypothesized under world systems theory)" (304). As global production disrupts customary livelihoods in southern countries, it creates a mobile population of workers and dependence at all levels on integration into the global market. Families manage risk by diversifying the economic activities of their members (new economics of labor). Countries manage their economies by exporting labor as well as goods, and wage differentials between southern and northern countries stimulate individual decisions to migrate. Over time, migration networks expand and become self-perpetuating (social capital theory and cumulative causation theory). Massey (1999) concludes that ultimately the sending country becomes more fully integrated into the global economy, or more 'developed,' and it then in turn becomes a country of immigration as opposed to emigration. This pattern is seen in countries such as Italy and Spain over the last 80-90 years, but (like demographic transition theories) it is unclear whether the "capitalist transition" historically seen in Europe applies universally and will occur for the current major sending countries.

The current migration climate is a 'postmodern paradox.' Global capitalism has at least paved the way for, if not directly caused, increasingly diverse flows of immigrants, yet the "modernization" that it inspires is also perceived as a threat. While northern countries benefit most economically in the aggregate, the economic benefits of migration for the receiving countries are very unevenly distributed and those at risk reassert "traditional' claims to ethnic nationality. Many southern countries are becoming highly dependent upon remittances, with significant portions of foreign income being sent by family members abroad. At an aggregate level both northern and southern countries increasingly feel their social and cultural national identities are threatened. The sense of economic and cultural risk has provoked increasingly restrictive migration policies in the most developed countries as well as growing cultural and religious "fundamentalisms" around the globe, thus both sending and receiving countries have a stake in immigration and modernization.

\section{Gender and Migration}

In the last twenty years, there has been an increasing amount of research on women and migration, which has begun to fill the gap created by the earlier focus on the stereotypical male labor migrant (Carling 2005). Women in earlier migration research were seen as companions to 
men, passive non-decision-makers in the migration process (Morokvasic 1984; Ong 1991). Currently, women migrate at same rate as men (United Nations 2006), so some of the inspiration to fill the gap arises because 'the invisibility of women in international migration scholarship does not correspond to the reality of international migration" (Pessar and Mahler 2003: 816). Further, women's migration experiences often differ significantly from men's (Pedraza 1991).

Early gender migration research has redressed the male bias by including women, by including gender as a variable differentiating among individual people. More current gender and migration research considers gender as a structure of relations that play out on multiple levels, from the individual to household, community, national and global levels. Hondagneu-Sotelo (1994) states this view clearly when she says that "gender is a set of social relations that organize immigration patterns...Gender relations [which are exercised in relational and dynamic ways] facilitate or constrain both women's and men's immigration and settlement" (3).

Gender research on migration emphasizes the agency of women and the importance of how men's and women's migration are similar and different. Kofman (1999) notes that “women's ability to maneuver a particular mode of entry often differs from that of men" (272) and specifically critiques the lack of research on the gendered experience of migration within the European context. Particularly, she asks scholars to "reconsider the neat classification of the development of European migration into an initial period of male labor migration followed sequentially by female family migration" (272, cf. Zlotnik 1995). Not only does this mean that there were female immigrants in Europe before the economic crisis in 1973, but also that by using a gender perspective we can better understand the nuances of negotiations involved in the process, uncovering the expectations, constraints and motivations for migrating.

Chant (1992) creates a framework for an analysis of gender-selective migration in developing countries highlighting the similarities and differences in how gender works in migration across different geographic areas ${ }^{10}$. The similarities found include: 1) the greater mobility of men compared to women, leaving women to deal with the consequences of male outmigration, which results in both giving increased autonomy to women while also burdening them with the survival of the family; 2) men's migration more often is linked to access to employment, varies in range of destinations, and occurs throughout the lifecourse. Female migrants are

\footnotetext{
${ }^{10}$ The major differences Chant found across geographical areas were the range of mobility of women, destination types, (i.e. rural, urban; small, medium, large city), types of work available to men and women.
} 
disproportionately young and single. Chant argues that there is less availability of work for women, and that women have more social and economic ties to place of origin. While there is reason to doubt that all these generalizations - especially the last - are still true, the empirical support for particular arguments is less important than the overall approach Chant takes to formulating a gender framework for understanding migration in structural terms. She importantly points out why men's and women's migration patterns may differ and how geographic differences are linked to different social and cultural gender regimes.

Furthermore, it is unavoidable to talk about gender and migration without talking about family and community. Chant and Radcliffe (1992) argue that a 'household strategies approach' to migration in developing countries appropriately captures the major gender dynamics of migration, though it could be argued that it fails to include a reciprocal effect of migration opportunities on how family strategies change. ${ }^{11}$ Gender divisions of labor, Chant reasons, provides a basic template for household decisions about who will migrate and who will stay. Specifically, she argues that a household strategies approach "highlights gender relations of unequal power [that] result in female responsibility for young children, and minimal male participation in household activities and decision-making, a situation which becomes onerous for older women who remain behind at the helm of the family economy" (23). Chant and Radcliffe's emphasis on family strategies puts a gender component into the new economics theory of migration.

Pessar and Mahler (2003) present an evolution in the thinking of gender and migration through their framework of 'gendered geographies of power.' Their framework integrates various gender perspectives on migration placing immigration in the context of global capitalism and transnationalism. Pessar and Mahler (2003) argue individuals and groups have particular social locations within 'interconnected power hierarchies,' such as class, race, sexuality, ethnicity, nationality and gender (816). These various social locations are created, reproduced and changed through historical, political, economic, geographic, and kinship relations. "The particular conditions of modernity that have produced time-space compression place people in very distinct locations regarding access to and power over flows and interconnections between places" (Pessar and Mahler 2003: 816). Additionally, not only are people's access to resources

\footnotetext{
${ }^{11}$ For more on changing household and family strategies see: To, Clara (2005). Intergenerational Contract, Women's Labor and Social Change in Contemporary Rural South China. UW Sociology Dissertation.
} 
and mobility across transnational spaces directly affected by social locations, but also people's "agency as initiators, refiners and transformers of these locations" (816). Pessar and Mahler (2003) place particular emphasis on individual initiative and the role of cognition and imagination prior to migration, which relates to the idea of anticipatory socialization. In this model, immigrants start changing their behavior in expectation of their migration. This applies to decision-making about children as well as gender relations. The question then becomes, how does migration reinforce or redefine or challenge hegemonic ideas of family and gender?

Like Massey, Pessar and Mahler emphasize the state's role in immigration. They argue that social benefits, citizenship regulations and political support are gendered. Gender equality is not supported by all governments, communities and families, which can lead to conflict when migrants are living across different gender regimes/contexts. However, as Mohanty (1988) and others have noted, transnational processes should not be universalized; it is a mistake to see the north as uniformly an experience of gender equality or women's emancipation, or the sending countries as particularly oppressive. Significant variation in women's equity in public and private life exists, from women who are not allowed to appear in public to women who are living transnational lives and take advantage of global consumer markets. Overall, we can conclude that migrants negotiate gender transnationally through: communication between spouses and family across borders; organization of work tasks when customary laborers are distant; negotiations about whether to stay or return at any given point; and changes in local gender regimes when migrants return home (Pessar and Mahlar 2003).

The work reviewed in this section suggests that Pessar and Mahler's 'gendered geographies of power' framework sets out an agenda that works well with Bongaarts and Watkins' social interaction framework and Massey's emphasis on the role of the state in migration. Fertility, migration, and gender are all negotiated at multiple levels. Migration impacts fertility and families by moving these processes to the transnational arena where decisions about fertility, family, work and residence are negotiated by households and states, with multiple mutable systems of gender and ideas about the nation-state.

\section{Migration-Fertility Hypotheses}

Despite the large body of research separately exploring migration, gender and fertility, the interactions between migration and fertility have been under-explored and under-theorized, 
especially in terms of gender. The majority of research on the impact of international migration on fertility has been conducted on migration to the United States, though there are a few notable exceptions (see Andersson 2004; Kulu 2005). From this work and the research on the impact of intra-national rural-urban migration on fertility, four major hypotheses about the relationship between migration and fertility have been proposed: socialization, selection, disruption, and adaptation (Kulu 2005).

The socialization hypothesis in a strict sense predicts that fertility levels would be the same in both contexts; migration would not affect fertility because childhood socialization is what matters most in fertility behavior. The socialization hypothesis is most associated with assimilation theory, which has generally gone by the wayside in migration studies. Nonetheless there has been some support for this hypothesis in studies showing that first-generation immigrants maintain fertility behavior of their sending country while second-generation immigrants have similar fertility behavior as the receiving country (in these studies, the U.S.) (Kahn 1988; Stehpen and Bean 1992).

The selection hypothesis suggests that migrants are a special group of people with distinct characteristics that account for their fertility behavior; the women who migrate are those who would have had fewer children anyway. Thus, women who have more than a primary education and who reside in urban areas are most likely to migrate. These women are already placed in the low fertility group of their society. This implies that for these women locale also does not matter, that certain type of women migrate. In regard to the selection hypothesis it is important to consider who migrates how and when. Like Pessar and Mahler argue, people come from different social locations and have differential access to migration opportunities Further, the nature of migration streams change over time, therefore, a selection bias from 1970 is most likely not applicable in the same way in 2006.

Disruption hypothesis states that the experience of migration lowers fertility before and upon arrival into the receiving country because the experience disrupts the migrant's life. This hypothesis has two facets. First, one disruption can be due to long term separation of a husband and wife. Alternatively, disruption can be a result of the preparation and anticipation to migrate and then subsequent difficulty to adapting to a new place that motivates couples to postpone child bearing. As a result either they have fewer children or they make up for not having children by having many in succession, recuperating lost fertility. 
Unlike the other theories adaptation theory considers the context into which the migrant is arriving as most influential, positing that migrants will exhibit fertility levels similar to nonmigrants at destination. Adaptation theory identifies two major factors that impact fertility behavior: resources and cultural norms. Resources consist of the living and opportunity costs associated with the receiving community such as cost of food, housing constraints, women having to work for wages, etc...These influences have direct and immediate effects on reproductive choices, particularly when women must do wage work to support their families instead of relying on the husband's income alone. Kulu (2005), in particular, emphasizes the importance of housing. He argues that the size of living spaces is related to overall living and opportunity costs which impact fertility decisions. This part of adaptation theory supports the economic aspects of fertility decision-making as well as the evaluative aspect of social interaction theory. Decisions about fertility are made in specific contexts. Interaction with other immigrants, government agencies, and the labor and housing markets impact gender relations and subsequent decisions about childbearing.

The second part of adaptation theory concerns the adaptation, or more commonly known as assimilation, of the receiving country's cultural norms. Interaction with friends, peers, coworkers, and others in the new environment shapes individual beliefs and desires, including such things as the meaning of parenthood and the value of children (Kulu 2005). This adaptation of new cultural norms is less immediate than the adaptation in regard to resource issues. Thus, it is seen most clearly in second generation immigrants; in this case, the children of, for example, women who migrated under family reunification laws. It also assumes interaction of the immigrant community and the native population as a whole, an issue we will address more carefully in considering the specific dynamics of migration to France.

These four hypotheses place different emphasis on sending and receiving countries, with socialization giving more weight to the sending country context and adaptation giving more weight to the receiving country context. Disruption can be placed in both contexts as women may 'disrupt' their fertility by delaying childbearing before migrating or continuing delaying or start recuperation immediately after migration. Selection focus much more on individuals' social locations. In the next section, I will draw together this theoretical material, focusing on 1) social location; 2) sending countries; 3) global context of migration stream; and 4) receiving countries. 


\section{E. Bringing it Back Together}

According to Bongaarts and Watkins, individuals do not make childbearing decisions in isolation. I believe that migration scholars like Massey (1999) and Pessar and Mahler (2003) would agree that individuals do not make migration decisions in isolation. How do individuals make decisions about vital events such as migration and fertility? According to Pessar and Mahler, each individual, or in their case, migrant, has a particular 'social location' from which she understands and experiences the world. This social location is part of 'interconnected power hierarchies,' which are defined by such attributes as class, education, ethnicity, nationality and gender. A woman's social location, particularly in regard to income, wage work, education, place of residence and marital status, impacts fertility outcomes. Women's different social locations impact their set of life options, including whether to migrate and how many children to bear. The emphasis on social location is parallel to the selection hypothesis which supposes that migrant women have particular characteristics associated with low fertility that make them also more likely to migrate. This is an important empirical question to consider and one that does not necessarily negate the others but rather may more beneficially be seen as one factor among several that determine fertility outcomes after migration.

The importance of social location, most emphatically emphasized by Pessar and Mahler (and gender scholars working on intersectionality), needs to be held in mind when considering the multiple multilevel factors contributing to what most consider very personal choices. Recognizing that individual women interact differently within specific social worlds, what kinds of information and ideas, evaluations and social influences are at play regarding decisions about vital events such as migration and childbearing, and more importantly, childbearing in the context of migration?

\section{Country of Origin}

I argue that the country of origin is an essential consideration in understanding the impact of migration on fertility. In different countries there are culturally specific local and national social interactions which are associated with fertility.

Local level

Social norms are primarily negotiated on a local level. Expectations of women and men in terms of their life choices about childbearing and migration are often highly gendered. Different cultures have different ideas about the place of motherhood and fertility. This paper 
concerns the normative case of a woman from the south migrating to the north. However, the south encompasses many countries and even within regions much variation exists on the importance and value of how many children a woman bears. These expectations also differ by social location, i.e. how many children a poor woman is expected to have compared to a rich woman is often different and varies by society. These fertility norms are, like all social norms, constantly under negotiation and change, as we have seen significant fertility declines in much of the world and some decline in Africa.

Migration also has social norms and institutions surrounding it. Migration streams have become somewhat institutionalized through networks and circular migration. The place of migration in a community varies. For some southern countries it has exploded in the last twenty years and has become a major part of their countries' economies. Migration strategies can be individual or family-based. How one migrates and the access to certain strategies greatly affects fertility decisions. It also creates different 'social imaginaries' of migration destinations. Migrating in the context of marriage means something very different than migrating to support a family who is staying back.

Social norms, according to those who support the socialization hypothesis of migrationfertility, are enacted in the receiving country. In the late 1980s, studies showed that sendingcountry fertility levels exerted a positive influence on immigrant fertility behavior, though they considered many immigrants as positively selected to easily adapt to the U.S. (Kahn 1988). Kathleen Ford's (1990) paper on the duration of residency and the fertility of U.S. immigrants complicates this view by looking at postponed fertility due to the anticipation of migration and the corresponding recuperation upon arrival. She highlights the importance of duration of residence suggesting that the more a woman's socialization occurred in the U.S. the more similar her fertility patterns would be to U.S. averages than those of her sending country. However, her findings were weak for Central and South American and Asian immigrants in comparison to European immigrants and do not include information on African immigrants.

To understand this aspect of the migration-fertility question, one must look at social interactions on the local level. This has implications for the types of social research employed. Generally, social interactions are best studied through qualitative methods such as ethnography, interviewing, focus groups and historical research which emphasize detail and locality. Quantitative research also can get at these interactions but is dependent on having attitudinal 
questions included in questionnaires. How do couples make decisions about migration and childbearing in a particular context? What role does family play in these decisions? What is the place of kinship networks? How are family relations structured? What is the value placed on childbearing? Are social norms regarding family, fertility and gender stable or changing?

\section{National level}

Development indicators: The national economy, though not related linearly to fertility, does impact fertility in significant ways. In addition to quality of life and employment issues, access to health care and reproductive health care in particular is more difficult in poorer countries. Mortality is also higher in poorer countries which is correlated with fertility. Variation among other background determinants of fertility, including, education and residence differs by country as does women's economic autonomy and gender relations.

Family planning programs: In general, immigrants from southern countries are coming from higher fertility contexts than the receiving country; however, these contexts are highly variable. One exception of this is Chinese immigrants in the US. Hwang and Saenz (1997) concluded that Chinese immigrants in the U.S. have more children then their counterparts in China. The one-child policy in China suppresses fertility; therefore, migration to the U.S. where no restrictions are placed on fertility allows Chinese women to achieve their desired fertility. This counter-example points out the importance of the respective national fertility contexts in determining fertility. Access to health care, family planning programs, government, media and NGOs working in reproductive health all contribute to the 'context' and understanding of the meaning of childbearing in a woman's life.

To understand the place the broader national context plays in the migration-fertility question, it is essential to know aggregate national demographic statistics and the institutional background in regard to fertility. Economics, child mortality, education, residential location and women's status have all been identified as indirect determinants of fertility. In terms of institutional background, one needs to know whether the government is heavily pronatalist or whether they are implementing national family planning programs. Is there access to reproductive health care, both pre- and post-natal? Are their many NGOs working on reproductive and gender issues? 


\section{Global Context of Migration Streams}

Migration occurs at particular times and between particular spaces. The major migration streams are from southern poor countries to northern rich countries. Sending countries are integrated into the global system to different degrees, have different historical relationships with receiving countries and are at the mercy of global labor demands and varying immigration laws.

Historical relationships between sending and receiving countries are a key component in understanding the impact of migration on fertility. Migration patterns such as Mexico-U.S. or Senegal-France are well tread paths supported by large networks and well established communities in receiving countries. Having a significant community in the receiving country lessens one's interaction with the dominant culture which may impact fertility choices. However, it also changes communication norms with family remaining in the country of origin, possibly affecting norms and behaviors there as well.

Global labor demands shape migration patterns both in terms of sheer numbers but also in terms of gender. At different historical moments, individual opportunities to migrate have varied. Women's migration has increased significantly and currently half of all migrants are women. This is in part due to changing labor demands on the world market; in the current global consumer culture, service industries have taken over manufacturing industries. There is higher demand for domestic workers, which is globally identified as 'women's work,' and when women respond to this opportunity by emigrating, this challenges local gender norms. Rhacel Salazar Parrenas' (2005) book Children of Global Migration: Transnational Families and Gendered Woes exemplifies how these labor demand changes have challenged the idealized patriarchal nuclear Filipino family. For both men and women emigration is understood within the context of an idealized patriarchal nuclear family. This means that a father's emigration is understood within the rubric of his role as the 'pillar of the family,' the primary breadwinner and thus is seen as legitimate, whereas a mother's emigration is understood within her role as 'the light of the family,' nurturing and caring directly for the family and therefore a last resort according to this 'gendered geographies of power' perspective on transnational Filipino families. Migration challenges gender relations and is set in a very particular family structure. Filipina women are migrating for work and to support their families in the Philippines, not to get married and start childbearing in the receiving country. 
Increasingly restrictive entry policies in many northern countries and economic decline in some southern countries have been the major factors contributing to new migration patterns. Sending countries are becoming dependent on foreign remittances as a significant part of their foreign income. This dependence is creating new family structures and new fertility patterns.

\section{Receiving Country}

\section{National level}

The role of the economy impacts immigrants significantly, as immigrants tend to work in the secondary market where job stability is rare. Thus, immigrants are differentially affected by poor economy. Immigration policies impact who gets to migrate, how and when. Further, immigration policies set rules for employment and integration into receiving country society. Social services, both educational and health related, also contribute to fertility decisions of migrants.

We primarily understand the impact of migration on fertility in terms of statistics. We compare fertility rates of women in the origin country with women immigrants and with native population in the receiving country. Anderson (2004) demonstrates that timing of migration is central to understanding immigrant fertility. More specifically, he argues that estimates of immigrant fertility rates are dependent on when in the lifecourse women are migrating. Thus, those migrating for marriage contribute heightened estimates of immigrant fertility since often the waiting time for visas and resources needed for migration delays first childbirth.

Correspondingly, Carter (2000) found that Mexican immigrant women who had already had two children experienced depressed fertility after migration. Toulemon (2004) also emphasizes age at migration in his work and suggests alternative ways of calculating TFRs for immigrant women in France due to their often delayed reproductive lives. These observations suggest that fertility estimates that do not consider timing of migration are overestimating fertility rates as fertility rates are estimated from survey data taken at a particular time and geography. Regardless of the

impact on fertility rates, migrating for marriage often delays first childbirth which is a disruption; immigrants' fertility patterns are different both from those in the country of origin and the receiving country.

Local level

To understand how women and men make decisions about childbearing, more than national context must be explored. How do immigrants interact with being in a new country on a 
daily basis? How are their fertility decisions affected by new jobs, housing, resources as in the adaptation hypothesis? How has the migration disrupted the immigrant woman's fertility? What are the major causes? How is gender relations affected by living in a new context with different gender rules? To what extent does an immigrant integrate into the new culture or segregate herself to a sub-community?

Timing of migration depends highly on how and why one migrates. Migrating for marriage is one common pattern in certain migration streams. Singley and Landale (1998) see migration from Puerto Rico to the U.S. as an integral part of family formation process. Using life history data from both origin and destination areas, Singley and Landale (1998) examined transitions to conception among migrant and nonmigrant Puerto Rican women. "Migration to and settlement in the U.S. may have different -indeed, opposite-implications for single women compared to women in unions" (1459). For Puerto Rican immigrant women, they found that migration lead to higher rates of transition to conception. These women were more likely to get pregnant outside of a married or cohabiting union and were also more likely to form a union than their counterparts in Puerto Rico.

Hondagneu-Sotelo (1994) shows a very different kind of family dynamic regarding migration. Studying Mexican migration to California, her research highlights how men's migration is much more linked to wage work than to a family strategy. She questions the place of family strategy within Mexico-California migration as husbands often delayed the reunification of the family and did not send remittances. Women followed their husbands but not in the expected way; many women used women's networks to immigrate, confront their husbands and to find work. In addition, she analyses the interaction of gender and prior socioeconomic status, concluding that immigrants' ability to negotiate and cope with life in California reflects the extent of downward mobility from their prior class status to the present one, and this stress then impacts the gender relations within the household. She also shows that women contribute most to the settlement process; she emphasizes the increased equality their waged work and U.S. cultural norms allow them. In the end, Mexican immigrant women are less likely to want to return to Mexico than men are. She does not study fertility specifically but her study shows the impact of migration on gender relations within families. Also, she shows in some cases that higher socioeconomic status and education is not the resource it was in the sending country and in fact those who were higher status had a harder time adjusting to their new lives. 
Women's desire to stay may be seen in Mexican women's fertility rates in the U.S. Contrary to socialization hypothesis, Carter (2000) showed that both temporary and permanent migration lowered fertility. Lindstrom and Saucedo's (2002) research corroborated these findings.

\section{F. Conclusion}

The integrated framework I propose above is meant to situate various research projects and information regarding the migration-fertility question. It raises important questions about the essential elements involved in the process of migration's impact on fertility. Next, I use this framework to examine an important migration stream that has received much media attention as of late, African migration to France. The French media portrays Africans immigrant women as having endless numbers of children and bleeding the social system. This exaggerated view characterizes very few African immigrant families. What is the fertility story of African immigrant women? African countries, though on average have significantly higher fertility rates than other continents, are at various stages of fertility transition. Thus, African immigrant women come to France with specific cultural values and ideas about childbearing. These fertility norms are different both from other immigrants, including Africans from other countries, as well as French women. I will use existing research to sketch out major factors involved in African immigrant fertility in France. Since I am using existing research, I am constrained by what others have produced; however, I hope the gaps will serve as inspiration for further work on the subject. Specifically, I have much more quantitative descriptive material which frames the picture but the details of social interaction need to be provided by further qualitative research in order to complete the image. 


\section{Fertility In Africa}

Fertility rates in sub-Saharan Africa are the highest in the world. The Total Fertility Rate (TFR) in sub-Saharan Africa is 5.5 children/woman (Bozon, Lelievre et al. 2001). This rate obscures the variation between countries; TFRs are highest in the Western and Central regions of Africa. The highest fertility rate on the continent is found in Niger, where women bear approximately 7.7 children in their lifetimes. ${ }^{12}$ Despite continuing high rates in some regions, there has been significant decline in countries such as Ghana, Kenya, southern Nigeria, Zimbabwe and South Africa (Cohen 1998; Caldwell and Caldwell 2002). As a region, southern Africa has the lowest fertility rates.

\section{A. Explaining African Fertility}

The major factors explaining African fertility include socio-economic development, mortality decline, and national family planning initiatives. Cultural issues including a desire for large families, the predominance of the extended family structure, and gender relations also play important roles in African fertility. In addition to these pan-African concerns, fertility rates vary within countries according to region and residential area, ethnicity, socio-economic status, and education and literacy. For this short review, I will focus primarily on variation in terms of place of residence (i.e. urban versus rural) and level of education. These characteristics are important because they can also be seen as individual characteristics of women, which are in turn correlated with the number of children a particular woman might have. Additionally, I address the rural-urban fertility differences and the migration-fertility question at an intra-national level. I conclude this section by presenting Bozon's typology of demographic patterns, which emphasizes demographic variation within African countries, and then, using the typology, examine the demographic context of four African countries that have migrants in France.

Bongaarts, Frank et al. (1984) argue that the processes that give rise to fertility differentials in sub-Saharan Africa are very different than those found elsewhere. Compared to other regions, socio-economic development remains low. Low socio-economic development makes access to health care facilities and to contraception more difficult. Mason (1997) particularly emphasizes problems of poor transport and communications as a major factor explaining African fertility. Along the same lines, Mason (1997) argues that mortality decline is

\footnotetext{
${ }^{12}$ See Appendix A for a map showing fertility rates in Africa.
} 
a precondition for fertility decline in Africa. Highlighting the importance of strong national family planning programs, Caldwell and Caldwell (2002) showed that sub-Saharan African countries that began fertility decline while the Human Development Index was low, such as Kenya and Ghana, had strong national family planning programs in place. ${ }^{13}$ Similarly, Kirk and Pillet (1998) explain fertility decline in Kenya and Zimbabwe as resulting from increased contraceptive use, which can be attributed to national family planning initiatives. ${ }^{14}$

In addition to the three major factors discussed above, many researchers highlight the importance of the social and cultural aspects of childbearing. In Africa, large families with extended kinship network have been normative. Thus, the desire for a large family motivates couples' fertility decisions. The use of contraception, for example, is not simply about being informed and having access but rather about the social importance and meaning of childbearing, making use of contraception more an issue of social acceptability than anything else (for example: Kaler and Watkins 2001; Bledsoe 2002; Kaler 2003). This explains low contraceptive use in societies where large families are desired. Further, it means that contraception is seen and used by women in specific ways for specific reasons. In the case of many West African countries contraception is most often used for birth spacing in order to insure the health of the mother and her children rather than for limiting the total number of births. In addition, in many African countries postnatal family controls further contribute to large family size. For instance, the tradition of child fosterage is common. This tradition relies on the predominance of the extended family structure in Africa, wherein it is typical for the responsibility for childrearing to be shared among a number of adults.

Caldwell's (1976) 'wealth flows' theory puts family structure, specifically extended family compared to nuclear families, at the center of understanding fertility. Family structure defines how resources are allocated. For extended families, high fertility is rational as children are responsible for taking care of their elders in old age; it is the basis of the security system. He argues that until the extended family norm breaks down, fertility will remain high in Africa. In

\footnotetext{
${ }^{13}$ Work by Courbage (1991) on Maghreb countries also point this out, explaining that the sharp fertility decline in North Africa during the 1980s is only slightly due to increases in urban living, education of women and very little difference is explained by women entering the work force. He links the decline to population control policies, Tunisia and Morocco instituted in the 1960s and Algeria in 1983.

14 A significant amount of research has been conducted in Kenya as they have had remarkable fertility decline in the last 20 years due to the implementation of a national family planning program. Susan Watkins has conducted numerous quantitative and qualitative studies on family planning programs in Kenya. (for example: Watkins and Rutenberg 1997; Watkins, Behrman et al. 2000)
} 
addition to the norm of the extended family, the majority of African families are patrilineal, meaning that an individual belongs to the father's lineage and that inheritance goes through the male line. Takyi and Dodoo (2005) address lineage and fertility choices of couples in their study on Ghana which evinced that women from matrilineal families were better able to implement their reproductive goals than women from patrilineal families. Their conclusion emphasizes the importance of gendered power relations within families as well as how the cultural context within which these dynamics play out aid or abate women's ability to implement their reproductive choices. A study by Dodoo and Tempenis' (2002) focused on traditional patriarchal kinship system in Kenya. They argue that urbanization has brought with it a breakdown in the traditional patriarchal kinship system and increased women's access to education and paid work, both of these factors give women more leveraging power to implement their reproductive choices. In rural areas, extended family systems are more intact, giving husbands more say in their wives' reproductive lives. This study shows how family structure and fertility decision making are gendered while also bringing up the next subject of education and residence, two major determinants of fertility.

\section{B. Education and Residence}

Bongaarts, Frank et al. (1984) ${ }^{15}$ and many other researcher have shown that urban, educated women have fewer children than rural women with little or no education. ${ }^{16}$ Lower fertility rates among better educated and urban women are caused by a later age at first union and higher rates of contraceptive use. Higher contraceptive use is due to greater access to family planning clinics in urban versus rural areas. Despite these fertility reducing attributes of urban areas, higher levels of education and urban residence are also associated with shorter durations of postpartum abstinence and breastfeeding, and lower sterility, all factors which increase fertility. Consequently, education and residence have both fertility enhancing and fertility reducing affects. Lesthaeghe (1984) also showed that use of contraception is high in regions with high literacy rates. Yet, only after literacy reached levels of 70 percent did fertility begin to decline. Further, given that educated, urban women are a small proportion of African women, this fact does not account for fertility decline in those countries that have seen significant change.

\footnotetext{
${ }^{15}$ Bongaarts and Potter (1983) proposed an earlier version of this model in 1983.

16 The extensive literature on the education-fertility relationship will not be reviewed extensively in this paper.
} 


\section{Rural-Urban Migration and Fertility}

Brockerhoff is the primary researcher who has dealt with the question of migration and urban-rural fertility differences in Africa. Brockerhoff and Yang (1994) show that migration to African urban areas leads to a decline in fertility around the time of migration; migrants are not a low fertility group that selectively migrates to the city; and the decline in migrant fertility is immediate and remains low, indicating that the circumstances of living in an urban area in themselves are conducive to fertility behavior change. He argues that this lower fertility is explained by an improvement in standard of living experienced by migrants and by temporary spousal separation. In an other article, Brockerhoff (1995) again shows that high spousal separation among migrants explains part of the rural-urban differences. Further, he identifies the increased migration of single women and increased use of modern contraception as key components of the different rates of fertility in urban compared to rural areas. His conclusion identifies the major proximate determinants of fertility decline, contraceptive use and the postponement of both marriage and childbearing because of increased migration by single women. An increase in migration among single women has been the biggest change over the last 20 years in Africa. It signals a breakdown in traditional patriarchal family structures.

More recently, Zamwangana Tungu (2005) examined the impact of rural migration to Kinshasa on fertility. His study shows that migrant women have basically identical patterns of fertility as native urbanites. He concludes that for both migrants and non-migrants the type of union and migratory status of the partner is linked to fertility. For migrants specifically, education, standard of living and the working status of the woman are associated with fertility. Compared to native urbanites, migrants therefore have more models of fertility which vary depending on these additional factors. Socioeconomic variables play different roles for migrants than non-migrants. Tungu concludes that migration changes attitudes and behavior which in turn change fertility. He believes that migrants have an important role in the diffusion of new fertility behaviors which would lead to an overall national fertility decline.

We see from the work of Brockerhoff and Tungu that how and why one migrates, particularly for women, impacts fertility behavior. In terms of resources such as housing and increased access to health care and contraception, life circumstances in urban areas are poles apart from those in rural areas. African fertility is going through major changes, via a variety of different mechanisms discussed above. These changes are occurring at different rates and in 
different ways in various countries, which is the subject of the next section in which I examine Bozon's demographic typology for Africa. From there I look more carefully at four countries, each one representing a different demographic type, in order to understand how sending country fertility context matters for fertility outcomes of African immigrant women in France.

\section{Demographic Patterns in Africa}

Over the last twenty years, Africa has experienced a considerable amount of demographic change. In terms of population growth, there has been extreme growth in some countries such as Niger and Mali and decline in countries devastated by civil strife, such as Liberia, and AIDS, such as Zambia and Zimbabwe. These very diverse demographic situations have implications for how we understand first fertility in Africa and then later what happens when Africans migrate to low-fertility developed countries. Bozon, Lelievre, and Munoz-Perez (2001) propose four main demographic transition patterns occurring in Africa: Traditional, Classical, AIDS perturbed and War-perturbed.

In the Traditional pattern, there has been some mortality decline but birth rates are still high. This pattern is common in very poor countries, such as Mali, which I will use as a case example later in the paper. In the Classical pattern, mortality has significantly declined over the last 50 years and birth rates have declined slowly. I will use Senegal to examine migration from this type of demographic patterned country to France. The last two patterns are associated with major decreases in population, the first of them being AIDS-perturbed such as in Zambia, Swaziland, and South Africa. Cameroon, which has a significant immigrant population in France, was included by Bozon et al. as an AIDS-perturbed model without having as high rates as the cases in Southern Africa where rates can be as high as 38 percent (Swaziland). Cameroon has one of the highest incidence rates in the Western and Central regions of Africa. Further, prevalence rates of seropositive HIV are considerably higher in Cameroon (5.5 \% in 2004, 6.8\% in 2003, and $11.8 \%$ in 2000) than either Mali or Senegal (both less than $2 \%$ ) (UNAIDS 2006). Six percent is still a significant number of people and it is affecting particular populations, such as women aged 25-29 of whom 1 in 10 are HIV positive. The War-perturbed pattern includes places such as Liberia, Sudan and Rwanda. I will use Rwandan refugees in France to exemplify this pattern. 
"Economic development, poverty, demographic and social policies, pandemics such as AIDS will determine each society's transition pattern in the next two or three decades, with each country following very different paths" (Bozon, Lelievre et al. 2001: 469). Migrating from these different types of countries means different things, is organized differently, and has different impacts on families and subsequent family formation.

\section{E. Cases: Mali, Senegal, Cameroon, and Rwanda}

In this section, I describe four sending country contexts focusing on those attributes that most define the fertility regime. I present the national development indicators (See Table 1 for a country comparison of the major development indicators), including gender development indicators and national family planning efforts. Then, I concentrate on national fertility statistics (See Table 2 for a country comparison of major fertility statistics) as well as more local examinations of various trends such as low contraceptive use.

Table 1. Development Indicators by Country

\begin{tabular}{lccccc}
\hline & $\begin{array}{l}\text { Total } \\
\text { population } \\
\text { mid-2006 } \\
\text { (millions) }\end{array}$ & $\begin{array}{l}\text { Life } \\
\text { expectancy }\end{array}$ & $\begin{array}{l}\text { Annual } \\
\text { per- } \\
\text { capita } \\
\text { income }\end{array}$ & $\begin{array}{l}\text { Percentage } \\
\text { of women } \\
\text { with no } \\
\text { education }\end{array}$ & $\begin{array}{l}\text { AIDS } \\
\text { rate }\end{array}$ \\
\hline Mali & 13.9 & 47.9 & $\$ 994$ & $80.0 \%$ & $1.7 \%$ \\
Senegal & 11.9 & 55.7 & $\$ 1,648$ & $59.7 \%$ & $0.9 \%$ \\
Cameroon & 17.3 & 45.8 & $\$ 2,118$ & $22.4 \%$ & $5.4 \%$ \\
Rwanda & 9.1 & 43.9 & $\$ 1,268$ & $29.4 \%$ & $3.1 \%$ \\
\hline
\end{tabular}

Sources : Mali UN Country Fact Sheet 2006 ; Senegal UN Country Fact Sheet 2006; Cameroon UN Country Fact Sheet 2006 ; Rwanda UN Country Fact Sheet 2006; UNAIDS; PRB 2006 
Table 2. Fertility Rates and Determinants by Country

\begin{tabular}{lccccc}
\hline & $\begin{array}{l}\text { Total } \\
\text { Fertility } \\
\text { Rate }\end{array}$ & $\begin{array}{l}\text { Married } \\
\text { women 15-49 } \\
\text { using any } \\
\text { contraception }\end{array}$ & $\begin{array}{l}\text { Average age } \\
\text { at first } \\
\text { marriage for } \\
\text { women 25- } \\
49\end{array}$ & $\begin{array}{l}\text { Average } \\
\text { age at } \\
\text { first birth } \\
\text { for } \\
\text { women } \\
25-49\end{array}$ & Polygamy \\
\hline Mali & 7.0 & $8.1 \%$ & 16.5 & 18.9 & $43 \%$ \\
Senegal & 5.3 & $28.6 \%$ & 18.3 & 20.5 & $39.5 \%$ \\
Cameroon & 5.0 & $28.4 \%$ & 17.6 & 19.1 & $30 \%$ \\
Rwanda & 5.8 & $13.2 \%$ & 20.7 & 22.0 & $12 \%$ \\
\hline
\end{tabular}

Sources: Mali DHS 2001; Senegal DHS 2005; Cameroon DHS 2004; Rwanda DHS 2000

\section{Mali, a Traditional Case}

National development indicators: Mali is a land-locked country in West Africa with very little arable land and desertification that is making agriculture less and less viable. Sixty-five percent of its land area is desert or semi-desert (CIA 2006). It is one of the poorest countries in the world ranking 174 out of 177 countries on the Human Development Index ${ }^{17}$ rating with an annual per-capita income of $\$ 994$ (Ulin 2006). Mali's economic instability is seen as being due to devaluation of the CFA, lack of access to international markets and deleterious impact of structural adjustment programs.

Currently, literacy rates and education levels in Mali are low. Only nineteen percent of the population is literate (Ulin 2006). Sixty-eight percent of Malian men cannot read compared to 85 percent of Malian women. Low literacy is linked to low education levels; sixty-six percent of males over the age of 6 have no education whereas 77 percent of females over the age of 6 have no education (80\% of women 15-49) (CPS/MS, DNSI et al. 2001). These gender differences are seen across all age groups. The differences in education level between urban and rural areas is dramatic; in rural areas 76 percent of males and 85 percent of females have no education whereas the figures are much lower in urban areas where 40 percent and 56 percent of

\footnotetext{
${ }^{17}$ The human development index (HDI) focuses on three measurable dimensions of human development: living a long and healthy life, being educated and having a decent standard of living. Thus it combines measures of life expectancy, school enrolment, literacy and income to allow a broader view of a country's development than does income alone.
} 
males and females respectively have no education. Blame for the education systems' woes have primarily been placed on the high population growth: it is significant that $48 \%$ of the Malian population is between 0 and 14 years of age.

Gender norms: The United Nations evaluates gender equality based on the gender-related development index (GDI). ${ }^{18}$ Mali ranks 136 out of 140 countries on the GDI, meaning that in terms of gender equality, Mali is one of the least equal. Another indicator of gender equality is the percentage of women in parliament; Mali ranks 108/140. Despite these dismal rankings, some researchers suggest that significant gender change is afoot in Mali. The economic crisis in Mali, with its decline in real wages and high unemployment among men, has increased women's participation in the labor market. In many families, women have become the main source of livelihoods. Vaa and Diallo (2002) suggest that through working outside the home, family roles and gender relations, particularly in urban households, are changing.

Tsafack and Calkins (2004) specifically look at the impact of migration on gender relations in Mali. They conclude that women's status improves when women migrate with their husbands, particularly if the woman has education which can help her find employment. Tsafack and Calkins suggest that migration lessens the social pressures of extended family members, the major policing faction of cultural gender expectations. Furthermore, return migration threatens gender advances accrued from migration. As part of the overall analysis of women's status regarding migration, Tsafack and Calkins explored the impact of migration on childbearing. They found that migration negatively impacts procreation through separation of partners, which supports the disruption hypothesis. Those who migrated together, however, did not have fewer children. Important to note, however, is that migrants are more likely to be in monogamous relationships and monogamous families have fewer children than polygamous families.

Family planning programs: Public health in Mali reflects the level of economic development. Sixty-three percent of the population lives less than $15 \mathrm{~km}$ from a health clinic (CPS/MS, DNSI et al. 2001). Access to potable water is insufficient and infectious and parasitic diseases spread easily. Reproductive health programs not only face similar problems as other health care programs in Mali, they also face significant barriers among the religious community

\footnotetext{
${ }^{18}$ The GDI was introduced in Human Development Report 1995. It measures achievements in the same dimensions using the same indicators as the HDI but captures inequalities in achievement between women and men. It is simply the HDI adjusted downward for gender inequality. The greater the gender disparity in basic human development, the lower is a country's GDI relative to its HDI.
} 
as 90 percent of the population is Muslim. Much debate has occurred over the place of contraception in the Islamic faith. A recent article posted on the USAID Mali mission web site described recent negotiations between religious leaders and reproductive health/family planning program leaders in addressing unmet need for contraception; the Mali DHS estimates unmet need for contraception at 29 percent. Religious leaders collaborated with USAID and the Ministry of Health to address the teachings of Islam regarding family planning. In addition to policy discussion between the two parties, the Islam, Population and Development Network (RIPOD) organized visits by religious leaders to health centers in Bamako. Religious leaders made presentations on Islam and birth spacing based on the Koran and teachings of Islam. These presentations clearly indicated that Islam is by no means opposed to birth spacing. This was the first time that imams in Mali openly discussed family planning-related issues (Maiga 2006).

The majority of reproductive health/family planning efforts is lead by foreign donors and NGOs. The first Community-Based Distribution (CBD) project was implemented in 1986 by the Center for Development and Population Activities; USAID and Save the Children have also sponsored CBD projects. Katz, West et al. (1998) evaluated Save the Children community based distribution program. They concluded that this method was successful at increasing contraceptive knowledge and practice because it integrated family planning services with an existing health care framework taking advantage of trained health care workers to supervise family planning promoters and insure sustainability.

Fertility: According to the 2001 Mali DHS, the urban total fertility rate is 5.5 (4.9 in Bamako) and the rural total fertility rate is 7.3. ${ }^{19}$ The fertility of Malian women varies by education and residence. Women with a secondary education or higher have fewer children (4.1 children) than women with primary education ( 6.6 children) and that of women with no education ( 7.1 children). When asked the ideal number of children, women respond with similar numbers to actual fertility rates, with 6.5 children the average ideal number of children; urban, educated women on average give lower ideal numbers of children than rural uneducated women. Malians desire high numbers of children and accomplish this through early marriage and first childbirth, continuation of polygamy and low use of contraception.

\footnotetext{
${ }^{19}$ For each case, I will use the Total fertility rate (TFR) indicator as defined for the Demographic and Health Surveys. Total fertility rate summarizes the current level of fertility. The TFR is calculated as the sum of the agespecific fertility rates multiplied by 5 (since each age group covers five years of age). The TFR represents the average number of children a woman would have at the end of her reproductive period if she were to follow the currently prevalent age-specific fertility rates (Ndiaye and Ayad 2006).
} 
Age at first marriage and first sex for women are both low at 16.5 and 15.8 years of age respectively. Correspondingly, forty percent of teenagers had begun childbearing at the time of the survey (CPS/MS, DNSI et al. 2001). The practice of polygamy is common in Mali; 43 percent of women in unions are in polygamous relationships. This practice is more visible in rural areas (45 percent) than in urban areas (34 percent). Moreover, a woman's level of education seems to play a determinant role on the type of union: women with no education are far more likely to be in a polygamous union (44 percent) than those with secondary and higher (26 percent) (CPS/MS, DNSI et al. 2001).

Women in polygamous families have been represented as being at odds with one and other, but Madhavan (2001) argues that Malian co-wives use both competitive and cooperative strategies to negotiate their positions in the domestic household. She emphasizes the importance of the cultural and socioeconomic circumstances and how they affect co-wives' relations. Regarding fertility, in Mali and many other African countries, a woman's status is based on her reproductive capabilities. Madhavan's (2001) research also explored the role of women's networks for impacting fertility. She found that the more involved the mother-in-law was in the couple's life the more children they have.

Since a woman's status in Mali is highly dependent on her reproductive capacities, the decision to use contraception is unlikely. Sixteen percent of women in union said they had used a modern contraceptive method at some time in their life. The women who most frequently use modern methods are those from urban areas (15 percent) and those who have had secondary education or higher (26 percent). Despite low contraception use, Malian women are well informed about modern methods of contraception; 76 percent of women know of at least one modern method of contraception with the pill and condom being the best-known methods (CPS/MS, DNSI et al. 2001). This result supports the findings of Kane and his colleagues (1998) who tested the effectiveness of a family planning media campaign in Bamako: various campaigns have been successful at disseminating information but not at changing the cultural norms around having many children. Andro, Hertrich and Robertson (2002) found that the probability of using contraception is determined more by men's expectation than by women's in Mali thus emphasizing the patriarchal organization of families.

Women do see some use for contraception. One out of four women identified birth spacing as accounting for the potential demand for family planning (26 percent). Further, among 
women who want another child, a significant majority (38 percent) wish to space the next birth by 2 years or more (CPS/MS, DNSI et al. 2001). Francine van de Walle and Mariem Maiga (1991) showed these same findings fifteen years ago: women know about contraception but rarely use it and if they do, they use it to space their children. Sarah Castle's research on contraceptive use in Mali puts Malian women's voices to these statistics.

Clandestine contraceptive users in Castle, Konate et al.'s study believed contraception is against Islam and will be bad for a woman's health (1999). They invited women to reflect on the perceptions of contraception. For some they believe it is contrary to Islam. "Some people say that it (family planning) is allowed; others that it is not. But what the religion does condemn is (its use) when the husband is not in agreement. If the husband agrees there is no problem". Others believe contraception will make one ill. "My husband says that (family planning) is not good... That it destroys a woman's genitals so that she subsequently won't be able to have children. He doesn't like me to talk about it." On the other hand another woman points out the benefits of using contraception to space children. “... but I see great benefit in spacing the children. If you fall pregnant while a child isn't very old or while a child can hardly walk that can impede his growth, because the heat that comes from a pregnant woman is really bad for sickly children." Others focus on the benefit to them, particularly regarding economics. "My husband doesn't give me anything -neither clothes for the children on festival days, nor their milk nor soap, let alone look after my needs. Everything comes from me. I don't even ask him, because if I do, it leads to a row" (Castle, Konate et al. 1999).

Castle's (2003) more recent study of peer-education programs among urban youth in Mali showed that "young people stated that they were wary of using either the pill or injectable contraceptives because they believed that these methods would make them sterile." Unmarried women's contraceptive behavior illustrates an emphasis maximizing fertility in order to gain status through childbearing when they are married, not limiting childbearing. In Mali, there is little evidence of changing attitudes and behavior towards fertility. It is from this very pro-natal context that women migrate.

Mali is an extremely poor country with low levels of education and limited women working outside the home; these factors are correlated with high fertility. Equally important, fertility in Mali is heavily entrenched in cultural norms and expectations. Malians value high fertility and women's status is linked to their reproductive capacities. Polygamy is still widely 
practiced encouraging high fertility. Contraception is rarely used and when it is used it is for child spacing to enable a woman to recover and prepare for her next pregnancy. These factors are strong and have not changed significantly despite the increase in emigration over the last twenty years.

\section{Senegal}

National development indicators: Mali's neighbor to the southwest, Senegal, has slightly stronger economy than Mali. In 2002, Senegal ranked 157 out of 177 countries in the Human Development Index, thus its economic health is not as dire as Mali. The average per capita income is significantly higher than Mali at \$1,648 a year. Nonetheless, during the time period 1990-2001, 33.4 percent of the population lived on $1 \$$ a day or less. On the economic side, in 1994, the Franc CFA was devalued by half impacting harshly the Senegalese economy and spurring migration. Unstable weather makes farming unpredictable and for the most part insufficient

Senegal has a higher rate of literacy than Mali with 39 percent of the population able to read (UNDP 2006). This differs significantly by gender; only 15 percent of Senegalese women being literate. Literacy reflects the education systems, which has not realized universal primary education. Women and men are over twice as likely to have never been to school in rural areas compared to urban. Thirty-seven percent of urban women are uneducated whereas 80.5 of rural women are uneducated. For men, the difference is equally dramatic; 26 percent of urban compared to 65 percent of rural men have no education.

Gender relations: Senegal ranks slightly better than Mali on the gender-related development index, ranking 120/140. However, in terms of female leadership, Senegal is doing significantly better, ranking 52/140 countries. There are few studies on gender in Senegal. Fisher et al. (2000) studied intrahousehold relationships with the adaptation of new technologies. They found that gender relationships affect the likelihood of adoption. New technology tends to increase the husband's income but not the wife's. Despite the negative impact on women's income, women supported stabling to provide milk year round because it benefited the family as a whole (Fisher, Warner et al. 2000). In Senegal, household income is not pooled, and femaleheaded households are becoming increasingly more common. Therefore, understanding of gender and family dynamics is essential to economic stability of families and communities. Dakar, Antoine and Dial (2003) also address family dynamics. Senegalese women are playing 
increasingly important roles in the economy, which has in turn contributed to increased average age of marriage and increased divorce. These gender norm shifts impact both fertility and migration decisions.

Family planning programs: In 1988, Senegal was the first country in Francophone Africa to implement a national population policy (Hardee, Agarwal et al. 1999). This implementation has changed rates of contraception, maternal mortality and circumcision only slightly. In Senegal, reproductive health as an objective is more culturally appropriate than family planning. In 1997, as a response from the 1994 International Population Conference in Cairo, the Senegalese government drafted a Program of Priority Actions and Investments in Population 1997-2001 in which 1/3 of the program focused on reproductive health. However, this program, despite its name, had few priorities and needed financial backing from western donors. The program was implemented in 1999. The Ministry of Health integrated services in 10 regions. However, lack of access and staffing was and remains an obstacle to care. Much reproductive health work is done through small community NGOs and women's groups which are foreign donor driven. For 2001-2006, the Ministry of Health with chosen district health collectivities and local and American technical assistance, are intervening in 29 districts to improve maternal and child health and stabilize the HIV/AIDS rates (Ministry of Health 2006). Thus, reproductive health seems to have some government support but is primarily donor driven.

Fertility: Fertility decline has been slow but consistent, with the TFR currently at 5.3 children per woman, a slow decline from 1986 when the TFR was 6.6 children per woman, typifying the classical demographic pattern as defined by Bozon et al. In Dakar 2005, the urban TFR was 3.7, including other urban areas raised it to 4.1. In rural areas women had an average of 6.4 children. The number of children a woman had was correlated with education with women with secondary education having half the number of children on average than women with no education (3.0 versus 6.1). Similarly striking is the age difference at first birth; on average women with no education had their first child when 19.4 years old whereas those with secondary or more had their first children at 25.6. At 20.5 years, the overall average age of first birth is higher than in Mali. Nineteen percent of women start bearing children during their teens (Ndiaye and Ayad 2006).

In a country that is 95 percent Muslim, marriage is the sanctioned institution for sexual activity and childbearing. Marriage is virtually universal and forty percent of married women 
are in polygamous marriages. Polygamy is significant, yet still least common in urban areas (33 percent), among highly educated (29 percent) and among the richest households (35 percent) (Ministere de la Sante, SERDHA et al. 1999). It is important to note that divorce is becoming more common for both men and women with almost universal remarriage, thus some argue there is little fertility disruption due to divorce (Locoh and Thiriat 1995). Lardoux and Van de Walle (2003) explore the relationship between polygamy and fertility using census data from rural areas, they find that within women in polygamous relationships and controlling for age and number of wives, the higher rank wife has higher fertility than lower ranked wives. Also, Lardoux and Van de Wall found that co-wives are highly likely to be pregnant at the same time.

Similar to Malians, the majority of women know some type of modern method (86 percent); urban, educated women all know some type of modern method. Despite knowledge of contraception only 16 percent of women have used modern contraception at some point. Of these women half use contraception regularly. Family spacing and rest for the mother are seen as legitimate reasons for using contraception (Ministere de la Sante, SERDHA et al. 1999). Randall and LeGrand (2003) support this finding with their qualitative research on fertility in Senegal. They emphasize that this is particularly true for those in rural areas. Furthermore, Randall and LeGrand show that in urban areas, the cost of children and the growing difficulties of child rearing justify desires for lower fertility. Another important factor in relation to fertility is child fostering. Vandermeersch and Chimere-Dan (2002) show that child fostering in Senegal "appears to be a mechanism for reducing demographic imbalance between households with too few children and those with too many" (680). Also, out-fostering is more common among mothers who have recently migrated and among mothers of lower socio-economic status.

In many ways, Senegal is very similar to Mali. They are both poor Muslim countries with low levels of education and slowly changing gender norms towards increased equality. Senegal compared to Mali, however, is further along in terms of transition to lower fertility. I suggest that this is because Senegal is just enough ahead of Mali economically and in terms of education to make a difference in fertility rates. Also, as I will show in the section on global migration, Senegal is more integrated into the global realm than Mali, which accounts for the lower fertility seen in Senegal. 


\section{Cameroon}

Cameroon differs in significant ways from both Mali and Senegal. Not only is the rate of HIV/AIDS higher, making it an AIDS-perturbed demographic type according to Bozon, but it also differs in terms of economics, religion, and education. I will address these factors first and then describe the fertility context. Finally, I will discuss how AIDS impacts fertility.

National development indicators: Cameroon's Human Development Index ranking is 148, higher than both Mali and Senegal and its' per capital annual income is significantly higher at $\$ 2,118$. The Cameroonian economy was strong in the 1970s and earlier 1980s, but in 1987 the value of Cameroonian exports fell significantly instigating 'la crise' economic decline that is still evident today. In 1992 the currency was devalued by 50 percent (Johnson-Hanks 2002).

Cameroon has significantly different educational and religious systems. English and French are the official languages, a colonial remnant; out of 10 administrative regions, 2 are English speaking and the rest are French speaking (Echu 2004). Literacy rates and education levels are significantly higher than either Mali or Senegal. Sixty-eight percent of the population is literate. This differs significantly by residence and gender. Only 11 percent of female urban dwellers (5 percent for male urban dwellers) have no education and in Yaounde/Douala basically everyone attends some school. Women are over twice as likely as men to never have gone to school. However, if a female enters school their progression to primary and secondary becomes more similar to males. Religious affiliation includes a significant proportion of Christians, mostly Catholic (approximately 40\%). Forty percent are Muslim and the other 20 percent practice local religions.

Gender relations: Cameroon ranks 113/140 on the gender-related development index. However, it has few women in parliament, ranking 125/140. Cameroon has had more women than Senegal and Mali participating in public life and working outside the home is not a new phenomenon there. A collection of works, Femmes $d u$ Cameroun, edited by Barbier (1985) thoughtfully address gender issues in Cameroon. The existence of such a collection, along with a few dissertations and other obscure articles, evinces the fact that gender issues have at the least been on the map for Cameroon for a longer time than for Senegal and Mali. Gender relations in Cameroon are significantly impacted by family structure. Around 30 percent of Cameroonian women are in polygamous marriages, primarily in rural areas. Typically, women in rural areas are responsible for taking care of the farm and producing goods for the family and for sale while 
their husbands earn wages in urban areas. This pattern was established during the colonial period with remnants of pre-colonial gendered labor patterns. Along with farm labor, women do the domestic labor as well, which leaves no time for wage labor and severely impacts women who are head of households. With improvements in education have come more opportunities for women to work in wage labor (Barbier 1985). Currently, 51 percent of women and 42 percent of men work in agriculture, leaving the rest to work in professional, sales, skilled labor, unskilled labor and domestic work (ORC Macro 2004).

Family planning programs/HIV/AIDS programs: Cameroon instituted the National Commission of Population in 1985 as an integrated part of their development strategy. Their health policies have been part of regional decision-making with a major program initiated in the early 1990s to improve primary health care and create a national health information system. In 2000, these objectives were expanded with the goal of having health clinics within an hour's walk away for 90 percent of the population. The new health sector objectives included reproductive health.

Cameroon created the National Program to Fight AIDS early in the epidemic, 1987. However, the program only started in 2000 with the goals of prevention, reduction of new cases, price reduction of antiviral medication, and the promotion of HIV/AIDS research. Mother-infant transmission and other vulnerable populations were prioritized. The Ministry of Health has partnered with private sector associations and donors to create a nation-wide response to the epidemic. Efforts have shown results with a significant reduction of HIV/AIDS rates. Nonetheless, HIV/AIDS continues to be a major public health concern (ORC Macro 2004). Fertility: The total fertility rate in Cameroon is 5.0 children per woman. This rate demonstrates a decline from 1991 when the TFR was 5.8 but a slight increase from 1998 (DHS 2004). These rates like those in Mali and Senegal differ by residence, education and living standard. In the capital, Yaounde/Douala, women have the least number of children on average (3.2). Rural areas are almost double with an average of 6.1 with other cities in the middle (4.6). Migration from rural to urban areas impacts fertility in Cameroon. Lee, using 1978 World Fertility Survey data, did not find significant fertility differences between rural-urban migrants and rural "stayers" (Lee 1992; Lee and Pol 1993). However, he argued that the impact of urban conditions which encourage small families were mediated by the fertility-increasing effects of reduced infertility, shorter duration of postpartum abstinence and breastfeeding and increased 
child survival. In addition, he found that for women with at least 6 years of schooling migration from rural to urban areas did produce lower fertility.

The link between education and fertility exists regardless of migration. Women with a secondary education or higher have fewer children (3.5 children) than women with no education (6.5 children). Twenty-nine percent of women under age 20 had begun childbearing (2004; INS and ORC Macro 2004). Only 3.6\% of currently married women 35-49 had never had a child and were thus considered sterile. Sixty-seven percent of women 15-49 were married at the time of the survey with only 2 percent of women single at age 35-39. Almost one in three women is in polygamous unions. Marriage occurs early with a median age of 17.6 years.

Johnson-Hanks (2002) investigated the relationship between education and fertility in Cameroon. Despite higher educated women having lower fertility than less educated women, women with secondary school were most likely to have premarital sex and premarital births. She shows how women's schooling relates to social factors like religion and ethnicity. She shows how being catholic and Beti leads to certain social practices which correspond with higher schooling (70 percent of all Beti speak French), greater economic and social resources as well as higher premarital sex and lower fertility, whereas on the other extreme is the Biu-Mandara which is a poor, rural Muslim community in which marriage is an economic necessity for women and there is high fertility and low premarital childbearing. Social factors interrelated so that "those communities that are most able and willing to send girls to school are also the most tolerant of low fertility, late marriage, and premarital childbearing" (168). Growing up Beti or BiuMandara impacts the expectations of a woman's future life, particularly in relation to schooling, marriage and motherhood.

Similar to other African countries, almost all women know about modern contraceptive methods yet few use them (14 percent). Johnson-Hanks (2002) in her study of the Beti in southcentral Cameroon argues that we need to think about the social context and social goals of couples. She studied the Beti because although they are only $1 / 5$ of the total population they make up half of current contraceptive users. In addition, historically the Beti have held high social status, education and financial resources. Periodic abstinence is the most common method of contraception, including for educated and urban women. "Beti women in southern Cameroon use periodic abstinence not only because they believe it to be effective, but also because it enables them to enact a disciplined, honorable, and modern identity" (230). The goal is not to 
terminate childbearing but to managing the timing of births by postponing first pregnancy and increasing birth spacing. Contraception is a social practice in which Beti women by choosing periodic abstinence are asserting their own type of modernity.

Now I will turn to Cameroon as an AIDS perturbed exemplar, first establishing the prevalence and then relating how AIDS can impact fertility. The majority of surveillance of HIV is done through prenatal and antenatal consultations. Buve et al (2001) showed that in four African villages the HIV rates of pregnant women was higher than that of men in the villages. The 2004 Demographic and Health Survey tested participants in order to estimate prevalence rates in 10 districts and the two major cities, Yaunde and Douala. HIV prevalence rates are 6.8 percent for women 15-49 and 4.1 percent for men 15-59. Highest prevalence rates are among women $25-29$ at 10.3 percent; among men those 30-34 are most likely to have HIV (8.9 percent). Prevalence rates differ by region with lowest rates in the North and highest in the Northwest. Rates also differ by education and socio-economic status with those with higher education and higher socioeconomic status having higher HIV rates. This last point coincides with JohnsonHanks findings of highly educated women not protecting against STDs when consciously delaying childbearing. Rates also vary by ethnicity and within ethnicities rates vary by gender. Women practicing new religions are also considerably more likely to be HIV positive than those of other religions. However, the rates among men do not differ significantly by religion (Institut National de la Statistique Ministere de la Planification 2005).

In 2002, the United Nations published a report on fertility and AIDS. First they pointed out that both AIDS can affect fertility desires and outcomes and fertility can affect the risk of AIDS. This causality dilemma exists because the proximate determinants for each are the same, i.e. sexual exposure, contraceptive practice, reproductive tract infection, breastfeeding practices.

Fertility rates are 40 percent lower for HIV positive women than those who are not infected. Since very few women know they are HIV positive until they start having AIDS symptoms they do not change behavior until well into the disease. So, some of the reduction of fertility in HIV positive women may be conscious behavior change; it is also possible that those women who become infected also have other STDs that prevent pregnancy or other intervening causes of reduced fertility. For those who are not infected, fertility desires are driven by social and economic considerations that are surprisingly robust in the face of the AIDS pandemic. "In formulating their fertility desires, individuals feel compelled to respect the existing structure of 
reproductive decision-making power along the dimensions of generation and gender" (United Nations 2002). That is to say that social and familial obligations trump health concerns.

Looking at the impact at the population level, higher rates of mortality often result in an increase in the level of fertility in the population as a whole because those who had lower fertility are no longer living; mortality from AIDS affects crude birth rates, fertility rates and the age-structure of a society. AIDS thus on individual and societal levels has the potential to change sexual practices, marriage and a host of factors that impact fertility. For the moment, however, social norms concerning childbearing outweigh the impact of the epidemic.

Like Senegal, Cameroon is in a transition to lower fertility. This transition is aided by a somewhat stronger economy, significantly higher education levels and greater participation in wage economy for women. In addition, Cameroon has implemented national reproductive health and HIV/AIDS prevention programs. HIV/AIDS has both negative and positive effects on fertility, making it difficult to determine its overall impact. Johnson-Hanks shows how culture plays into fertility decision-making for the Beti, making fertility postponement a symbol of the modern Cameroonian woman.

\section{Rwanda}

Rwanda is probably more similar to Cameroon; however, the experience of genocide in 1996 makes Rwanda drastically different from any of the other three countries both in terms of fertility and migration. Here, I will present the demographic background and then explore how being a war-perturbed country impacts fertility.

National development indicators: Rwanda is more similar to Senegal in terms of HDI ranking and average annual income (159 and \$1268) than to Mali or Cameroon. Rwanda has an HIV rate of $3.1 \%$ (down from 5.1\%) (UNAIDS 2006). Ninety-three percent of the population is Christian, primarily Catholic. The official language is Kinyarwanda, which is spoken by the entire population; French, English and Swahili are also common languages used (Office National de la Population and Macro 2001).

Rwandans, like Cameroonians, have high literacy and education rates. Sixty-four percent of all Rwandans are literate (Ulin 2006). Literacy varies by gender, residence and wealth. Women are more likely than men to be unable to read (29 percent compared to 22 percent). Educational attainment is not surprisingly also higher for men than women. However, compared 
to Mali, Senegal and Cameroon, gender disparity is less strong. Twenty four percent of women have no education compared to 17 percent of men.

Gender relations: The gender related development index ranking for Rwanda is similar to Senegal (122/140). However, Rwanda has the most women in parliament of the countries included in the UN rankings, highlighting significant efforts made towards gender equity. The Rwandan government has taken strategic affirmative action measures to ensure female participation in political and economic arenas. Specifically, discriminatory inheritance and land ownership laws have been overturned and special efforts have been prioritized in support of HIV prevention for women and increased education. Resultant of the war, 34 percent of all Rwandan households are headed by women (Morel-Seytoux and Lalonde 2002). Twenty-eight percent are headed by widows. Thus, more female friendly policies are needed to support these families. However, Morel-Seytoux and Lalonde point out that cultural and social norms challenge the status of women in Rwanda. However, it is clear that Rwanda is in a time of transition and renegotiation of women's place in society.

Family planning: In 1982, Rwanda developed a family planning initiative that was adopted in 1990. The initiative was geared specifically toward reducing fertility through family planning in order to control population growth. After the 1994 genocide, a new population policy was developed which integrated the demographic goals with socioeconomic goals. The Ministry of Health in collaboration with donors supports these goals through increased health budgets and support for reproductive health programs and HIV/AIDS mother-to-child transmission programs (Office National de la Population and Macro 2001).

Fertility: The Rwanda DHS 2000 shows that the TFR was 5.8 compared to 6.2 in 1992 and 8.5 in 1983 (Office National de la Population and Macro 2001). Like the other African countries we have discussed so far, the TFR varies by education level and residence but not nearly as much as the other countries examined. Women with no education have an average of 6.1 children compared to an average of 4.9 for women with a secondary education or more. Urban women have on average 5.2 children whereas rural women have 5.9. Only $6.8 \%$ of women under 20 years old had started childbearing, which is lower than for Mali, Senegal and Cameroon. This finding corresponds with average age at marriage which is 24.4 and 20.7 for men and women respectively. The average age of that kind for Rwandan women is considerably higher than for the other countries examined here. Polygamy is considerably less common than 
in the other three countries; 12 percent of all married women have one or more co-spouses. As far as knowledge and use of contraception, Rwanda is similar to other African countries; knowledge is basically universal (95\%) while utilization is low, 13 percent of married women use modern methods and 8 percent use traditional methods (Office National de la Population and Macro 2001).

Not surprisingly, there has been little research produced on the reproductive health of war-affected populations. Therese McGinn (2000) attempts to fill this gap in a review article published in International Family Planning Perspectives. In the article she looks at the following issues regarding war-affected populations: fertility and family planning, safe motherhood, STDs, HIV/AIDS and sexual and gender based violence. Here I will briefly discuss the impact of forced migration on fertility and gender based violence.

There are two contradictory positions regarding impact of forced migration on fertility. The first states that fertility rises because of the pressure to replace deceased children and warriors. The second argues that fertility falls because the stress and uncertainties of refugee life are not conducive to childbearing. Research has not been conclusive but does emphasize the post-migration context as well as social and demographic characteristics. Those who have resources are less likely to have disrupted fertility; this can mean individual and family resources as well as the situation in the refugee camp or asylum country. Some studies have shown that some refugees have better access to healthcare than they did in their conflict-affected country of origin (Hynes, Sheik et al. 2002; Verwimp and Van Bavel 2004). "In sum, these studies suggest that no common fertility pattern emerges among refugees. The immediacy and severity of an emergency may affect short-term response, but in the long term refugees' fertility appears to be influenced by social and demographic factors long associated with fertility change" (McGinn 2000).

Migration-Fertility: Verwimp and Van Bavel (2004) compare reproductive patterns of Rwandan women who stayed and those who left their homes returning again after 1994. This is not the same as looking at those who permanently move but will give us an idea of the factors involved in reproductive choices after a crisis such as that occurred in Rwanda. Verwimp and Van Bavel (2004) evaluate two major hypothesis of the impact of forced migration on fertility. The first hypothesis emphasizes the insurance role of children under conditions of economic insecurity. In this hypothesis "fertility rises among refugees as a response to lower child survival: 
high child mortality entails a pressure to replace deceased children" (3). This hypothesis parallels fertility transition theories which emphasize the reduction of child mortality as essential to fertility decline. The opposite hypothesis states that fertility declines because of the stress and conditions of refugee life are not conducive to childbearing. This second hypothesis is similar to the disruption hypothesis. Findings support old-age security theories of reproductive behavior, as refugee women had higher fertility, however their children had lower survival rates, which disproportionately affected girls, a product of the refugee camp conditions (Verwimp and Van Bavel 2004).

Rwanda is another African country in fertility transition. The genocide left Rwanda in chaos. From this chaos comes a rebuilding of government policies on reproductive health and HIV/AIDS. Reasonably high rates of literacy also play a part in women's access to wage work and lowering rates of fertility. The impact of the war inside Rwanda seems to be both positive and negative in terms of fertility, keeping Rwandan fertility at pre-war levels. Migration due to the genocide also seems to have mixed effects. In particular, Verwimp and Van Bavel (2004) give support to Pessar and Mahler's emphasis on personal social location, i.e. access to resources helps women achieve their fertility decision-making goals.

\section{F. Conclusion}

In this section I have attempted to highlight the variation among African countries. Indeed similarities exist, such as poverty, gender inequality, high birth rates, etc. Yet, when looked at more closely the differences have implications for future fertility decision-making. Of the four countries, Mali has not yet seen a drop in fertility. There are a few glimmers of change regarding social norms towards family planning but no official population policies. The economic and educational situation as well as widely held religious beliefs does not foreshadow a society on the brink of fertility transition. The other three countries, on the other hand, have all seen steady fertility declines. Senegal has started fertility decline, which places a female migrant or possible migrant, in a different 'social imaginary' about her current and future fertility choices than one who is in a society where childbearing norms are more inert. Cameroon is in a similar position but faces more significant problems of HIV/AIDS, which has lead to greater national efforts in the realm of reproductive and public health. HIV/AIDS has been shown to have both positive and negative effects on fertility. It remains to be seen what kind of effect this would 
have on women migrants in France if any. More significant I believe is the increased access to wage employment for women. Furthermore, Cameroonians and Rwandans have higher education levels than either Malians or Senegalese and many of the migrants to France are Christian, two factors that give Rwandan and Cameroonian migrants greater ability to integrate into French society, possibly impacting fertility decision-making. Finally, Rwandan migrants are leaving a situation of conflict, most likely without their husbands and possibly with some or all of their children. The conditions of their migration are significantly different from the other three countries and most likely also varies among the Rwandans in France in terms of what length of time their asylum will be granted, and whether citizenship is granted. McGinn suggests that fertility can be impacted both negatively and positively by war. She made two important points: one, that access to health care may be better in the refugee camp or in this case, France, would positively affect fertility; and two, the importance of assets and resources in mediating hardships associated with refugee status. Most important in the case of Rwandans in France is that they are most likely estranged from their partners. 


\section{Global Migration Patterns}

\section{A. African Migration}

Africa as a region is second only to Latin America in its percentage of its population emigrating with no replacement immigrants (United Nations 2006). ${ }^{20}$ Barou (2002) demonstrates that not only have the numbers of Africans migrating increased, but there are more African countries sending immigrants than ever before increasing the types of migrants, changing the structure of "African" migration. Historically, if Africans migrated externally it was most likely to their former colonial ruler, Britain or France. However, this has changed and African migrants have diversified their destinations. Nonetheless, two-thirds of West African immigrants in the 1960s-1980s had Europe as their primary destination, including notably Italy and Portugal which were former countries of high emigration. France ranks $5^{\text {th }}$, after the US, the Russian Federation, Germany and Ukraine, for having the largest general international migrant stock in 2005 (6,471,000 migrants). The UK and Spain are also within the top 10 countries with the largest migration stock, 2005 (United Nations 2006).

African migration follows the beginning pattern of capitalist transition theory as laid out by Massey. Subsistence farming and other customary livelihoods in Africa do not sufficiently support the growing populations in Africa. The Sahel's expansion and desertification as well as drought in other areas have forced out-migration. More significantly, global markets reach into every corner and village, disrupting African economies. Debt and the subsequent structural adjustment programs (SAP) of the 1990s augment these disparities and have increased poverty in many African countries. The SAP increased income inequalities within countries, reflecting global social inequalities. Consequently, this has created a mobile population of African workers and dependence on the global market. Families manage risk through migration of some of their members who attempt to take advantage of wage differentials between southern and northern countries. Professionals and educated elites more easily migrate creating a significant 'brain drain.' Labor has become for many African countries their major export. This process overtime has become self-perpetuating, increasing the African Diaspora significantly. This process includes broad networks and has changed over time in response to economic decline, global

\footnotetext{
${ }^{20}$ Emigration data is hard to come by and when available does not include the substantial amount of illegal migrants.
} 
market demands, and increasingly restrictive immigration policies by northern countries. This more recent African emigration is becoming increasingly diversified, with growing numbers migrating to other European countries as well as North America, including the United States.

\section{B. Migration from Mali, Senegal, Cameroon, Rwanda}

Of our cases, Mali and Senegal have similar migration histories while Cameroon and Rwanda are both different from Mali and Senegal and from each other. Mali and Senegal as former colonies and neighboring countries have similar migration patterns. Both have long histories of internal migration (Findley 1993), which has been the major strategy to support individual households and extended families facing poverty and seasonal dry periods (Pison, Gabadinho et al. 2001). Internal migration in Mali, according to de Haan, Brock et al. (2002), needs to be conceptualized as part of sustainable livelihoods which combines agro-pastoral activities, livelihood diversification and migration. Sustainable livelihoods in rural areas are strongly embedded in kinship networks, notions of obligation and reciprocity. De Haan and colleagues emphasize the structuration of migration, the institutionalization of the practice as part of social relations and economic support, which is similar to cumulative causation theory mentioned in relation to Massey's capitalist transitions theory. The Soninke community of the Senegal Fleuve Valley region is one context where migration has become institutionalized. This region encompasses parts of Mali, Senegal, Guinea, and Mauritania. International migration from other areas of Mali and Senegal has vastly increased, thus the Fleuve Valley does not stand out in the same way it once did.

Both Senegal and Mali are sending more of their population than they are receiving. For the 2000-2005 period, Mali had a net of 27,000 people emigrate, which corresponds to a net migration rate of -2.1 migrant(s)/1,000 population. Similarly, Senegal had 20,000 people leave during the same period, which is a net migration rate of -1.8/1000 (United Nations 2006). These migrants are making significant contributions to Malian and Senegalese economies. During 2000-2005, remittances made up 3.1 percent of Mali's GNP, receiving \$154,000,000 in remittances. Even more impressive is the contributions of Senegalese migrants with $\$ 511,000,000$ sent during the same time period, making up 6.7 percent of the GDP (United Nations 2006). 
Cameroon and Rwanda differ from both Senegal and Mali as well as from each other. Both have low but positive net migration rates and numbers for 2000-2005 are 0.2/1,000 (3,000 total) and 1.1/1000 (9,000 total), respectively. Similarly, remittances make up only a very small percentage of their GDP; for 2004, only 0.1 percent of the Cameroonian GDP and 0.4 percent of the Rwandan GDP. However, Cameroon has particularly high internal migration rates; Cameroonians from the extreme north, west and north-west migrate most often, making up 53 percent of all internal migrants (Schrieder 2000); these regions are the most highly populated for the limited resources of the regions. Yaunde and Douala are the major receivers of these migrants. As a result of economic crisis in the late 1980s to early 1990s, migration patterns have changed. Rural-urban migration has reversed in response to drastic cuts in public employee salaries. The unemployed returned to their villages of origin. Cameroonians also sought employment internationally. Cameroon in particular has been referenced in terms of the "brain drain' with many professionals seeking work in developed countries.

Not included in Massey's framework, migration due to political instability and conflict has increased. During the time period 1969-1990, 43 civil wars were fought in the world; 17 of those 43 were in Africa. Rwanda is one case of many: Rwanda, Burundi, Zaire, Liberia, Somalia, and Sudan. Rwanda has been a country of emigration due to internal strife since 1955. However, the most recent civil conflict was in 1994 and incited large numbers of Rwandans to leave the country. Between 800,000 to 1,071,000 Tutsis and moderate Hutus in Rwanda were killed during a 100-day period between April and July, 1994. This was approximately 10 percent of the Rwandan population. Seventy-five percent of the Tutsi population was killed. The mayhem produced a massive refugee crisis and left almost 100,000 children orphaned. The majority of refugees sought refuge in the Democratic Republic of the Congo (Zaire) with significant number of refugees in Burundi, Tanzania, Uganda, and Zambia (Straus 2006). Rwandans who make it to France have gotten there through various different paths; many have spent time in refugee camps and in other countries of asylum before arriving in France. Rape and sexual violence, which occurs both as weapon of war and in refugee camps has been used for justification for asylum (McGinn 2000). 


\section{Africa, Gender and Migration}

Over the last 30 years, family reunification has increased female international migration greatly and has been the major avenue through which women migrated, to join their husbands. International migration from West Africa is largely dominated by men (Antoine 1997). For example in Mali men migrate between 1.3 and 1.8 times more often than women (Antoine 1997). This pattern is changing globally with more women migrating independently and as main income-earners instead of following male relatives (Adepoju 2004). One explanation for this is that there has been an increase in mono-parental households in many sub-Saharan countries, making the mother the primary income earner. Parrenas shows us that global market demand influences who migrates. In her case, Filipina women were migrating to work as domestics. Service jobs such as domestic work, child care, elder care, health care, are female coded jobs in rich countries. Not only are they female coded jobs but they are raced jobs as well. These types of jobs are the largest growing employment whereas male coded jobs in industry are declining. Feminization of migration challenges standard conceptions of Africa-Europe migration and highlights the social changes concerning gender in the African migration process (Barou 2002).

If migration impacts gender relations, it also impacts family structure. International migration changes family structures spreading family across time and space. Pessar and Mahler identify many of the ways families 'do family' in the transnational context. She shows how men try to hold onto their status and 'control' of their wives by using relatives and community members as checks. Parrenas shows how mothers try to 'mother' via phone calls and packages. Another example of transnational families includes those men who have migrated, leaving a wife and children, and then marrying again in the new country. These transnational polygamous families function in very different ways and have different challenges and problems than families who exist in the same nation. Lubkemann (2000) warns that those wives who stay in rural areas working as subsistence producers allow husbands to keep their land while also reducing remittances. Thus, men have incentive for keeping them away from urban life which may lead them to question their role. Migration in many African countries has become a rite of passage. Furthermore, it has become an affirmation of masculinity and value as a husband (Levitt 1998). Levitt quotes one return migrant as saying, "this is the life. I am John Travolta now." Migration is negotiated in gendered ways within families and communities; migration both challenges and reinforces ideas about hegemonic femininity and masculinity. 


\section{Africa Migration to France}

Migration from Africa to France existed since colonization but did not become significant until after World War II. More specifically, as Italy and Portugal, traditionally sending countries to France, improved economically, North Africa began to fill labor demands. The Algerian war (1954-1962) increased migration flow from other former African colonies since the war cut off the Algerian pool of migrant workers. Independence from France in the early 1960s sparked additional labor migration flows from ex-colonies such as Mali and Senegal. The 1973 economic crisis led France, and other European countries, to discontinue labor migration in July 1974. Since 1974, family reunification has been the major avenue of legal entry into France as well as other European countries; seventy percent of all legal entries from non-EEA countries are for family reunification (Bilsborrow 1992). Since the mid-1980s, in addition to family reunification, education and asylum have also become major motivations for migration to France. The changes from primarily male labor migration to family, education and asylum migration has changed the gender make up of the migration population in France. Women now make up 48 percent of the sub-Saharan immigrant population (INSEE 1999). Emigration from sub-Saharan Africa has increased dramatically in the last twenty years. Between 1999 and mid-2004, sub-Saharan African migration to France increased with 45 percent (Borrel 2006).

Currently, 10.7 percent of the total population in France is foreign born (Muenz 2006). ${ }^{21}$ Sub-Saharan Africans make up 9\% of the total foreign born population in France (INSEE 1999). In the last full census taken in 1999, the Senegalese were the largest immigrant group from subSaharan Africa in France with a population of 53,859 (INSEE 1999). ${ }^{22}$ The Malian and Cameroonian communities were significant as well with populations of 35,978 and 26,890 respectively (INSEE 1999). There are 2,400 Rwandans in France (INSEE 1999).

\section{E. Conclusion}

Africa's increasing economic woes are fueling migration and instigating a 'feminization of migration,' meaning that migration from Africa does not take the historically dominant form of men migrating for wage labor and instead we are seeing an array of different migration

\footnotetext{
${ }^{21}$ Foreigners. This includes individuals in France who were born abroad as well as children, under the age of 18, who were born in France of immigrant parents. It also includes any individual born in France of foreign parents who chooses not to adopt French nationality at the age of 18 . The numbers include those who have taken French nationality and those who have not.

${ }^{22}$ This figure is from the 1999 census and does not include the number of illegal immigrants living in France.
} 
patterns. Not only are we seeing a change in who is migrating, we are also seeing a restriction of immigration laws in major receiving countries like France. Economic pressures and increased barriers to migration impact individuals and families in new ways that deserve attention. Emigration data is notoriously difficult and scarce, but would be invaluable for better understanding these dynamics. Furthermore, circular migration, communication strategies within families, evolving migration strategies and more detailed political background are all important areas for further research which would fill out the global context's effect on the migration-fertility nexus. 


\section{CONTEXTUAL FACTORS IMPACTING AFRICAN IMMIGRANT FERTILITY IN FRANCE}

In France, the statistics on legal immigrants show that the total fertility rate of subSaharan immigrants is 2.86, significantly lower than for their counterparts in Africa and closer to the native French fertility rate of 1.74 children/woman (INSEE 1999; Toulemon 2004) ${ }^{23}$. It is essential to note that not only does this not include illegal immigrants, a significant population, but it combines all of sub-Saharan immigrants to come up with an average. This general pattern also describes most cases of migration from poor to rich countries. Generally in the case of migration from a southern to a northern country immigrant fertility is higher than the native population and lower than women who stayed in their country of origin. Unfortunately, there are no available statistics to show fertility rates by single country of origin. Sub-Saharan Africans make up a significant yet small part of the entire French population and its higher rates make only a small difference in the overall fertility of women living in France, whose TFR is 1.8.

What are the major factors in France that contribute to African immigrant fertility rates? For all immigrants, fertility is impacted by: 1. immigration policies, 2 . the economy and housing; 3. social services and access to health care; and 4. changes in gender norms. Despite facing similar challenges, immigrants interact with these institutions differently depending on their country of origin. Malian, Senegalese, Cameroonian and Rwandan immigrants have different migration histories and fertility norms.

\section{A. Immigration Policies}

After the 1974 ban on labor migration, family reunification became the primary legal mode of migration to France. French policy towards immigrants in the 1960s and 1970s was to assimilate immigrants into French culture consistent with France's citizenship policies stressing 'French'-ness, the cultural values and norms associated with being French over having French blood. The second half of the 1970s saw increased efforts to limit family reunification (Brubaker 1992). The election of Francois Mitterand in 1981 brought more integrationist policies and liberalized residency and work permits. The mid-1980s, nevertheless, brought the antiimmigrant agenda of the National Front led by Jean-Marie Le Pen that has been successful in continuing to restrict immigrant policies.

\footnotetext{
${ }^{23}$ Toulemon argues for a different method of calculated fertility of immigrants based on their different patterns of childbearing since the majority postpone childbearing until arriving in France.
} 
In 1986 and 1993, the Pasqua laws were implemented, the most restrictive immigration laws in France's history:

The so-called Pasqua Laws prohibited foreign graduates from accepting in-country employment, increased the waiting period for family reunification from one to two years, and denied residence permits to foreign spouses who had been in France illegally prior to marrying. The legislation also enhanced the powers of police to deport foreigners and eliminated opportunities to appeal asylum rejections. The election of a conservative president in 1995 continued the course of limiting immigration channels (Hamilton, Simon et al. 2004).

The 1993 Pasqua laws also outlawed polygamy forcing polygamous immigrant families in France to separate; this law in particular was not enforced until around 2000 and has negatively impacted a portion of Malian and Senegalese families.

As a result of the Pasqua laws, permanent entries declined until 1997 when immigration streams increased once again. In 1997 with a change to a socialist government, immigration laws were adapted to allow highly skilled workers, students, scholars, and scientists special immigrant status, while simultaneously combating illegal immigration. In addition, 87,000 illegal immigrants were regularized. In 2003, an additional immigration law was passed providing "stricter regulations to combat illegal immigration and to regulate the admission and stay of foreigners in France" (Hamilton, Simon et al. 2004). Despite increasingly restrictive policies and a poor economy, immigration continues to rise enlarging the illegal immigrant population.

Current laws includes the following restrictions and changes: 1 . Only the qualified get "skills and talents" residency permit; 2. Foreigners are only allowed in to work, not live off benefits; 3. Foreign spouses need to wait longer for residence cards; 4. Migrants must agree to learn French; 5. Migrants must sign 'contract' respecting French way of life; and 6. Scrapping of law on workers getting citizenship after 10 years. As of last July, 13,000 immigrants were departed; the Ministry of Interior's goal is to deport 25,000 in 2006. Last July, new immigration and integration laws were adopted which will extend these restrictions and will significantly impact immigrants lives starting from early 2007. The four main objectives of the new law are to recruit skilled workers, facilitate foreign students' stay, tighten rules on family reunification and limit access to residence and citizenship (Murphy 2006). 
The changing rules on family reunification and residency and citizenship will have the most impact on immigrants, particularly in terms of family creation and fertility. Not only must France's basic principles of family life be respected (secular state, gender equality and monogamy) and 'real will' to integrate be shown through language and civic course attendance, immigrants will have no access to social or medical benefits unless they are working or studying. Waiting periods for reunification have been increased from 12 to 18 months and spouses of French citizens must wait three years, instead of two, before applying for a 10 year residency permit. Four years of marriage to a French citizen are required to be eligible for citizenship (Murphy 2006)

Citizenship is a key indicator of integration. Low rates of acquisition of French citizenship and low rates of women indicate strong ties with country of origin and less integration into French society (Barou 2002). Overall patterns show that those immigrant groups with high percentages of French citizenship are those in which women are more numerous, play important economic roles in the family, and have higher education levels, and thus are more integrated overall into French society.

The immigration law changes have significant implications for fertility of sub-Saharan immigrants. The increasing requirements for legal entry will increase the selectivity of immigrants, which would in effect lessen the likelihood of possible 'higher' fertility women from entering France. With legal access barred for greater numbers, illegal immigration will increase, increasing the expense for migration and thus limiting larger portions of the sending community, increasing selectivity. There is also the potential for the growth of illegal immigration networks that exploit and place those wanting to migrate in danger. Further, the waiting periods for family reunification have the potential to change women's life course patterns which would impact on when African immigrants have children and how many. Increased waiting periods potentially increase disruption of fertility both pre and post migration. The various impacts of the new laws are not initiated by the implementation of new laws but rather exacerbate already existing challenges and problems.

\section{B. Economic Factors}

The two major economic factors affecting immigrant groups in France are the economy and housing. Since the change from the French Franc to the Euro, the cost of living has 
increased significantly. This has taken a heavy toll on the poor, which includes a large proportion of the sub-Saharan African immigrant population. Financial instability of many immigrants is a key component of their experience in France and may reduce or increase the number of children a woman bears.

\section{Economy}

The first African immigrants came in response to a strong economy and high need of labor. Currently, in the France metropolitan area the overall unemployment rates are at 10 percent, with non-immigrants with a percentage of 9 and immigrants twice as likely to be unemployed at 18 percent (Thave 2000). The economic opportunities are much more limited than the immigrants imagined. Youth and African immigrants make up a large proportion of these unemployed immigrants. In 1999, sub-Saharan Africans aged 20-29 had unemployment rates of 27 percent (Thave 2000).

Immigrants disproportionately work in non-skilled, low wage labor, which is different for men and women. Men tend to work in construction and the automobile industry, a declining job sector. Women are more likely to do temporary or part-time work and are concentrated in the service industry, particularly as 'femmes de ménage,' which is part of a growing job sector. Immigrant women have increased their employment significantly, increasing from 41 percent in 1982 to 57 percent in 2000 (Borrel and Boëldieu 2001). These statistics are only for those immigrants working legally, many legal and illegal immigrants are working non-formally in similar sectors receiving sub-standard wages and working in poor conditions. These gendered work conditions affect fertility because employed women tend to have fewer children than nonemployed women. Additionally, financial struggles are known to cause problems within couples and having a wife and mother work may be a significant cultural shift. Finally, the cost of raising children is higher and often extended family networks are not immediately available to lessen the burden. These economic factors fit into the adaptation hypothesis which emphasizes the impact of resources on fertility decision-making.

\section{Residence}

Sixty percent of sub-Saharan immigrants live in Ile-de-France (Borrel 2006). 570,000 sub-Saharans live in metropolitan France (Borrel 2006). Malians, Senegalese and Congolese are proportionally more numerous in public housing than in private housing. These buildings are large collective buildings primarily in the suburbs and are inadequately maintained. These 
housing units were never meant to be permanent but temporary housing for temporary workers who would leave when they were no longer needed. This temporary housing has become permanent for many immigrants and the placement of these housing units in addition to the soaring prices of rent and real estate in Paris proper has led to racial segregation where with the exception of certain enclaves like the $18^{\text {th }}$ district of Paris most sub-Saharan Africans live in the suburbs. Of all sub-Saharan immigrant groups Cameroonians are most likely to own their living spaces.

Racial segregation reduces sub-Saharan African's contact with native French. Subcultural groups, i.e. Malians, Senegalese, Cameroonians, are then isolated, creating their own communities with their own social norms, thus not integrating into 'French' culture. Also, immigrants who come to France without being able to speaking French can isolate themselves in communities where they rather speak their first language. So, those coming from high fertility countries, such as Mali, can continue to place high value on childbearing. However, residential space is also a significant factor, whereas in Africa, particularly in rural areas, space is more plentiful. In Paris, many immigrants are living in small crowed living situations, which is likely to depress fertility.

\section{Interaction with Social Institutions}

As with Lesclingand's findings regarding internal migration in Mali, gender also plays an important role in Malian immigrant women experience in France; Carolyn Sargent shows the importance of gender in migration of African immigrants, particularly in regard to reproduction. Sargent and Cordell (2003) argue that migration from West Africa to France disrupt shared understandings of marriage and reproduction. In France, marriage and reproductive norms disapprove of polygamy and high fertility, two important facets of Malian culture. Immigrant women interact with diverse medical and educational institutions, such as prenatal clinics, maternity hospitals, well-baby clinics and primary schools. These interactions help women adapt more easily to the Parisian social environment than immigrant men which parallels findings of Pierrette Hondagneu-Sotelo and Catherine Quiminal. They also introduce via interaction with institutional authorities such as nurses and social workers views on reproduction that contrast with those of their husbands and their community of origin. Thus, immigrant women receive pressure to have children by their husbands and family while simultaneously receiving pressure 
to use contraception by French health care providers through their interaction with maternity and child health care clinics. Not surprisingly the issue of contraception becomes a central issue of marital conflicts. Men resent this interference as it lessens their control over their wives' fertility (Timera 1996; Quiminal 2002).

\section{Changing Gender Norms}

Catherine Quiminal's (2002) work on West African immigrants highlights that women who migrate under family reunification are isolated in multiple ways: by being restricted from working legally for 5 years after arrival, often because they are not literate, ghettoized into lowincome foyers and traditional gender roles. For the men who often work in low paid, low skilled jobs, being able to have a wife at home gains respect thus it is in his interest to keep her secluded from French society and other resources that may challenge cultural assumptions about gender. Men complain of the 'femme reveillee' the awoken woman, a woman who is not dependent on her husband, dangerous woman who might 'show him the door.' By learning how to read and write French, interacting with others outside the community, contacting social assistance and working for wages, women defy the authority of men, upsetting the Soninké gender norms. The men understand that keeping their women uneducated and financially dependent is what keeps the established order of marital relations. Thus, men scorn education and waged work for women. Education and waged work then are both empowering and possibly constraining due to men's reactions. Quminal's study on the Soninké shows how gender is socially constructed and reconstructed during the process of migration.

Quiminal's research on West African associations gives a gender perspective on the relationship between the sending country and receiving country. Quiminal (2000) shows that women immigrants tend to create Pan-African associations to deal with the everyday problems of living in France whereas men create associations affiliated with the African villages from which they come. This is similar to Hondgneu-Sotelo's work with Mexican immigrants and highlights the affiliation men have with their home villages underscoring their traditional position within the household. More specifically, in the case of Senegal, Quiminal shows that retaining contact with important men in Senegal and other Senegalese men in Paris gives them status within the immigrant community. 


\section{E. The Situation of Malians, Senegalese, Cameroonians and Rwandans in France}

Malians, Senegalese, Cameroonians and Rwandans have similar experiences as Africans in France. However, they experience immigration and subsequent fertility decisions differently based on the migration and fertility regime characteristics unique to their country of origin. As Malian and Senegalese immigrants are more similar to each other than Cameroonian and Rwandan immigrants, I will discuss the Malian and Senegalese together and then the Cameroonians and Rwandans together.

\section{Malian and Senegalese Immigrants}

Two major characteristics of Malian and Senegalese families have been prominent in French public discourse: polygamy and pronatalism. Estimates suggest that 1/3 of Malian female immigrants in France are living in polygamous unions (Timera 1996). This figure is lower than for Mali which is estimated at 43 percent overall with higher levels in rural areas. However, it is important to note that there are still more Malian men than women living in France. Furthermore, men can be in transnational polygamous unions with a wife in France and one or more wives residing in Africa. This is particularly true considering the enforcement of the Pasqua laws forbidding polygamy in France. Thus, the decline seen in polygamy is not necessarily a change in attitudes or behavior but reactions to outlaw of polygamy and other constraints and preferences. The Pasqua laws mentioned earlier, particularly in regard to polygamy, have induced unintended consequences within polygamous families as co-wives strategize to enhance their reproductive capacities in order to be the wife who is allowed to stay in France (Sargent and Cordell 2003; Sargent 2005). "Polygamy functions with difficulty in France, given modest household budgets, shortage of adequate lodging, and difficulties in managing conflicts among co-wives obliged to co-habit with their respective children in a restricted and uncomfortable space" (Timera 1996; Sargent and Cordell 2003: 1963).

The major Malian and Senegalese migration pattern is for young Malian women to arrive in France to join their husbands. They often have little formal education or French language skills. They tend to be isolated, leaving home primarily to shop or visit health centers and children's schools. Despite these similarities, Senegalese seem more integrated into French society than Malians. The Malian immigrant population in France is 65 percent male and only 15.8 percent of the Malian immigrant population has citizenship (INSEE 1999). These last two factors highlight that this population still sees their migration as temporary as well as their lack 
of integration into French society. Among the Senegalese, 33 percent have French citizenship. Forty-two percent of the Senegalese population is female. These percentages show that the population is more settled and integrated into French society than Malians.

Forty percent of Malian families have 4 or more children living with them (INSEE 1999). This statistic is considerably higher than for any other immigrant group. Though there are no exact statistics on the number of children Malian women bear, the medical community daily observations at clinics support the idea that Malian women continue to have large families. In comparison, only 20 percent of Senegalese families have four or more children living with them (INED 1999). Twenty-seven percent of Senegalese households in France are monoparental (INED 1999). Of the monoparental Senegalese households, the majority (87 percent) were headed by women. Senegalese households are twice as likely to be monoparental as the rest of the immigrant population (INED 1999). This suggests significant changes in family norms from Senegal to France, particularly in regard to gender norms. A typical immigration story told by many Senegalese confirms these statistics. In the typical scenario, a Senegalese man has immigrated to France. Through family connections he arranges to marry a Senegalese woman. The woman comes, they start a family. Then the wife becomes restless, feeling isolated she finds ways to get education, language skills, employment. Her new found freedom changes her ideas about marriage and gender, thus moving her to reject the patriarchal relationship patterned after 'traditional' customs of her home country. The woman, through the support of government assistance and employment, can then leave her relationship if is it unsatisfactory.

To a large extent, family and reproductive tendencies reflect the situation from which they came. Fertility in Mali has not shown any decline or promise of decline. Pronatalism is strong. Malian immigrants are still primarily male, despite increases in female migration. Rarely do Malians have children outside of unions and it seems that Malian immigrant women are having more children than other groups of women. Mali out of all of the cases highlights the importance of socialization. Senegal, as a classical case, has seen slow but steady decline. There is evidence of changing mores, with lower household sizes and significant numbers of monoparental households. The transitional state of Senegalese fertility then becomes played out in the migration to France. 


\section{Cameroonian and Rwandan Immigrants}

There is much less research on Cameroonian and Rwandan immigrants in France than on Malians and Senegalese. Cameroonians represent both 'the new immigrants,' immigrants with higher skill sets, more education and fluency in French making them more readily adaptable to French society. HIV/AIDS seem to have two possible affects on fertility, neither which could be directly discernable from what I have read, seen or heard. However, we should consider the likelihood of the most affected groups to migrate. Those from high risk groups are probably not the most likely to migrate. Selectivity effects are important in not only which groups migrate but also a more general selectivity of Cameroonians having attributes amenable to fertility change. They migrate from a society in fertility transition having relatively high education, higher rates of women working in wage employment, more single women raising children and most likely a Catholic religious upbringing. These factors set Cameroonians up to more easily have a high percentage of French citizenship, by acquisition at 36 percent, indicating significant commitment to living in France and 'being' French (Barou 2002).

Rwandans with such a particular reason for migration and such a small population are a select group. To get to France they most likely have significant social and financial capital. They are most likely to be educated and Christian. More important than having these attributes, is that most Rwandan women in France are separated from their partners, who are dead, in prison or possibly in a refugee camp. Families were torn apart after the genocide, being sent to different camps in different countries. Many Rwandan women were sexually assaulted during the war, which has been an important claim for asylum. Rwandan women are not migrating to marry and start a family. Furthermore, the instability of their situation, being in France on asylum status does not lead to any stabilization; they cannot be employed and do not know how long their asylum status will last, both factors non-conducive to childbearing. 


\section{CONCLUSION AND OUTLOOK}

Migrant identity is the object of a continual process of restructuring, as migrants negotiate everyday life in France. One facet of this process involves the perceived value of childbearing and of children (Sargent and Cordell 2003). This paper has attempted to emphasize that migration includes experiences that cross both time and space. Thus, in considering the impact of migration on fertility, one must consider multiple levels of social interaction. First, individuals have particular social locations that are associated with varied social and economic capital that sets out different choices for those of different classes, education levels, nationalities, and genders. Secondly, the demographic patterns and cultural mores of the sending country need to be considered in order to better understand the impact of migration on fertility. The global context determines what destination choices are available for potential migrants. It sets the stage of economic and political relationships between countries and shows the extent to which a country is integrated into global society. This potentially impacts fertility because of how it defines and constrains life course decisions. Finally, the receiving country's specific immigration policies, economy, social services, and gender relations impact the context in which women make their fertility decisions.

Africans have common experiences of poverty and higher than average fertility rates. Yet, the different cases examined here - the traditional, classic, HIV/AIDS-perturbed and warperturbed demographic patterns - highlight how French immigrants come from specific social and demographic locations which prepare migrants to negotiate fertility decisions differently. The most important sending country factors include whether the country has started fertility decline, the economic and social situation, and existence of a recent catastrophe like war or epidemic such as HIV/AIDS. Coming from a country of transition means that women and men are actively negotiating norms around childbearing, which also indicates negotiation around family, the role of women, and gender norms more broadly.

Immigration policies have become increasingly restrictive, making it difficult for immigrants without highly marketable skills to enter legally. Between the economic problems in many African countries and the increasingly restrictive policies, new immigrants are more likely to have more education, some money, include more women, and more likely to want French (or other European) citizenship (Barou 2002). The illiterate African unskilled worker is not the dominant figure of this population. Less skilled immigrants strategize ways to get around these 
policies, but with such restrictions illegal migration becomes one of the few options increasing the precariousness of their situations. Furthermore, the scarcity of jobs even for those with legal status make simply survival challenging, not to mention raising children and negotiating changes in gender expectations and responsibilities. Immigrants face a weak economy and racism in looking for employment and housing. This is further exacerbated for those without papers. Reflecting global labor trends, the job market is gendered and women's work in domestic arenas, such as 'femme de menage'-cleaning woman, child minders, and old age care are in higher demand than typical masculine low skill jobs. Both the economic and political situation strain gender relations within the sub-Saharan African communities, thereby, transforming and reevaluating the place and meaning of reproduction.

This paper only hits the tip of the iceberg in comprehending the processes and experiences of Afro-French immigrants. Focusing on the multiple levels of social interaction regarding fertility highlights the gender dimensions in couple's decisions to have children. Much more research must be done to understand the French fertility context for sub-Saharan African immigrants. I have argued that all African countries are not the same in regard to fertility norms, some are in more transition phases than others, making their reproductive decisions in France more of a place of negotiation. These negotiations are gendered in nature, questioning the meaning of being women and men immigrants in France. For Senegalese and Cameroonians, this describes their situation. On the other hand, Cameroonians have better education, French language skills and similar religious beliefs as native French that allow them to better integrate into French society. I suggest better integration leads to increased adoption of French fertility norms. Data on specific immigrant groups need to be gathered to further explore this possibility. Rwandans are most similar to Cameroonians, except for their experience with genocide which drastically marks immigrants' lives in France and thus their fertility decisions. Childbearing, I suggest, is not as prominent for Rwandans for this reason. Sow (1999) states that migration is not only a change in geography, but also a qualitative change in social relations. In the case of migration's impact on fertility, these changes in social relations started in the country of origin, play a part of why sub-Saharan Africans are migrating and how they negotiate subsequent social relations, including childbearing in France. 


\section{Acknowledgements}

I am grateful for comments and helpful advice from Gunnar Andersson, Caroline Bledsoe, Gerda

Neyer, Betty Thomson, Myra Marx Ferree, Gay Seidman, Sara Hertog, Erika Cottrell, and Keera Allendorf, as well as institutional support from the Max Planck Institute for Demographic

Research in Rostock, INED in Paris, and the Department of Sociology and Center for Demography and Ecology at University of Wisconsin-Madison.

\section{References}

(2004). Cameroon 2004 Executive Summary (English). Calverton, MD, ORC Macro.

Adepoju, A. (2004). Trends in international migration in and from Africa. International migration: Prospects and policies in a global market. D. Massey and Taylor: 59-75.

Andersson, G. (2004). "Childbearing After Migration: Fertility Patterns of Foreign-born Women in Sweden." International Migration Review 38(2): 747-775.

Andro, A., V. Hertrich, et al. (2002). "Demand for Contraception in Sahelian Countries: Are Men's and Women's Expectations Converging? Burkina Faso and Mali, Compared to Ghana." Population 57(6): 929-957.

Antoine, P. (1997). L'Urbanisation en Afrique et ses Perspectives. Dakar, Senegal, REMUAO.

Antoine, P. and F. B. Dial (2003). Mariage, Divorce et Remariage a Dakar et Lome. Dakar, IRD Dakar-UR CIPRE.

Barbier, J.-C. (1985). Femmes du Cameroun: meres pacifique, femmes rebelles. Paris, Karthala.

Barou, J. (2002). "Les immigrations africaines en France au tournant du siècle." Hommes et Migrations 1239(Septembre-octobre).

Bilsborrow, R. (1992). "Preliminary Report of the United Nations Expert Group Meeting on the Feminization of Internal Migration." International Migration Review 26(Spring): 138161.

Bledsoe, C. (2002). Contingent Lives. Chicago, IL, University of Chicago Press.

Bongaarts, J., O. Frank, et al. (1984). "The Proximate Determinants of Fertility in Sub-Saharan Africa." Population and Development Review 10(3): 511-537.

Bongaarts, J. and R. G. Potter (1983). Fertility, Biology, and Behavior: An Analysis of the Proximate Determinants. New York, Academic Press. 
Bongaarts, J. and S. C. Watkins (1996). "Social Interactions and Contemporary Fertility Transitions." Population and Development Review 22(4): 639-682.

Borrel, C. (2006). Enquêtes annuelles de recensement 2004 et 2005 Près de 5 millions d'immigrés à la mi-2004. Paris, France, Cellule Statistiques et études sur l'immigration, INSEE.

Borrel, C. and J. Boëldieu (2001). Recensement de la population de 1999 - De plus en plus de femmes immigrées sur le marché du travail. Paris, Insee.

Boserup, E. (1970). Woman's role in economic development. New York, St. Martin's Press.

Bozon, M., E. Lelievre, et al. (2001). Demography of the World's Regions: Situations and Trends. Paris, INED.

Brockerhoff, M. (1995). "Fertility and Family Planning in African Cities: the Impact of Female Migration." Journal of Biosocial Science 27: 347-358.

Brockerhoff, M. a. X. Y. (1994). "Impact of Migration on Fertility in Sub-Saharan Africa." Social Biology 41(1-2): 19-43.

Buvé, A., K. Bishikwabo-Nsarhaza, et al. (2001). "The spread and effect of HIV-1 infection in sub-Saharan Africa." The Lancet 359(9322): 2011-2017.

Caldwell, J. C. (1976). "Toward a Restatement of Demographic Transition Theory." Population and Development Review 2(No. 3/4. (Sep.-Dec., 1976)): 321-366.

Caldwell, J. C. and P. Caldwell (1987). "The Cultural Context of High Fertility in sub-Saharan Africa." Population and Development Review 13(3): 409-437.

Caldwell, J. C. and P. Caldwell (2002). "Africa: The New Family Planning Frontier." Studies in family planning 33(1): 76-86.

Carling, J. (2005). Gender dimensions of international migration. Geneva, Switzerland, Global Commision on International Migration: 22.

Carter, M. (2000). "Fertility of Mexican Immigrant Women in the U.S.: A Closer Look." Social Science Quarterly 81(4).

Casterline, J. (2001). "The Pace of Fertility Transition: National Patterns in the Second Half of the Twentieth Century." Population and Development Review 27(Supplement:Global Fertility Transition): 17-52.

Castle, S. (2003). "Factors Influencing Young Malians' Reluctance to Use Hormonal Contraception." Studies in Family Planning 34(3): 186-199. 
Castle, S., M. K. Konate, et al. (1999). "A Qualitative Study of Clandestine Contraceptive Use in Urban Mali." Studies in family planning 30(3): 231-248.

Chant, S. (1992). Conclusion: towards a framework for the analysis of gender-selective migration. Gender and Migration in Developing Countries. S. Chant. London, Belhaven: 197-206.

Chant, S. and S. Radcliff (1992). Introduction. Gender and Migration in Developing Countries.

S. Chant. London, Belhaven Press: 1-29.

CIA (2006). The World Factbook: Mali, CIA. 2006.

Cleland, J. and C. Wilson (1987). "Demand transitions of the fertility transition: an iconoclastic view." Populations Studies 41: 5-30.

Coale, A. (1973). The Demographic Transition Reconsidered. International Population Conference, Liege, Belgium.

Coale, A. and S. Watkins (1985). The Decline of Fertility in Europe. Princeton, NJ, Princeton University Press.

Cohen, B. (1998). "The Emerging Fertility Transition in Sub-Saharan Africa." World Development 26(8): 1431-1461.

Coleman, D. (2006). "Immigration and Ethnic Change in Low-Fertility Countries: A Third Demographic Transition." Population and Development Review 32(3): 401-446.

Courbage, Y. (1991). Demographic Transition among the Maghreb Peoples of North Africa and in the Emigrant Community Abroad.

CPS/MS, DNSI, et al. (2001). Enquete Demographique et de Sante Mali. Calverton, Maryland, USA, Cellule de Planification et de Statistique du Ministere de la Sante (CPS/MS), Direction Nationale de la Statistique et de l'Informatique (DNSI) et ORC Macro.

De Bruijn, B. J. (2006). Chapter 39: Fertility: Theories, Frameworks, Models, Concepts. Demography: Analysis and Synthesis. G. Caselli, J. Vallin and G. Wunsch. Amsterdam, Elsevier Inc.: 549-569.

de Haan, A., K. Brock, et al. (2002). "Migration, Livelihoods and Institutions: Contrasting Patterns of Migration in Mali." Labor Mobility and Rural Society: 37-58.

Dodoo, F. N.-A. and M. Tempenis (2002). "Gender, Power, and Reproduction: Rural-Urban Differences in the Relationship Between Fertility Goals and Contraceptive Use in Kenya." Rural Sociology 67(1): 46-70. 
Easterlin, R. A. (1975). "An economic framework for fertility analysis." Studies in Family Planning 6(3): 54-63.

Echu, G. (2004). "The Language Question in Cameroon." Linquistik online 18.

Findley, S. (1993). "Choosing between African and French destinations; the role of family and community factors in migration from the Senegal River Valley."

Fisher, M., R. Warner, et al. (2000). "GENDER AND AGRICULTURAL CHANGE: CROPLIVESTOCK INTEGRATION IN SENEGAL." Society and Natural Resources 13(3).

Ford, K. (1990). "Duration of Residence in the United States and the Fertility of U.S. Immigrants." International Migration Review 24(1): 34-68.

Ginsburg, F. and R. Rapp (1991). "The Politics of Reproduction." Annual Review of Anthropology 20: 311-343.

Hamilton, K., P. Simon, et al. (2004). The Challenge of French Diversity, Migration Policy Institute.

Hardee, K., K. Agarwal, et al. (1999). "Reproductive Health Policies and Programs in Eight Countries: Progress Since Cairo." International Family Planning Perspectives 25(Jan): S2-S9.

Hondagneu-Sotelo, P. (1994). Gendered Transitions: Mexican Experiences of Immigration. Berkeley, University of California Press.

Hwang, S.-S. and R. Saenz (1997). "Fertility of Chinese Immigrantsin the U.S.: Testing a Fertility Emancipation Hypothesis." Journal of Marriage and the Family 59(February): 50-61.

Hynes, M., M. Sheik, et al. (2002). "Reproductive Health Indicators and Outcomes Among Refugee and Internally Displaced Persons in Postemergency Phase." American Medical Association.

INS and ORC Macro (2004). Enquete Demographique et de Sante Cameroun 2004. Calverton, Maryland USA, Institut National de la Statistique (INS) Ministere de la Planification de la Programmation du developpement et de l'Amenagement du Territoire and ORC Macro. INSEE (1999). Immigrées selon le pays d'origine, INSEE. 2006.

INSEE (1999). Population: Immigres et etrangers en Ile-de-France. Paris, INSEE. 
Institut National de la Statistique Ministere de la Planification, d. 1. P. d. D. e. d. 1. A. d. T. a. O.

M. (2005). Cameroun Enquete Demographique et de Sante 2004. Yaounde, Cameroun;Calverton, Maryland USA.

Johnson-Hanks, J. (2002). "Education, Ethnicity, and Reproductive Practice in Cameroon." Population 58(2): 154-179.

Johnson-Hanks, J. (2002). "On the Modernity of Traditional Contraception: Time and the Social Context of Fertility." Population and Development Review 28(2): 229-249.

Kahn, J. R. (1988). "Immigrant Selectivity and Fertility Adaptation in the United States." Social Forces 67(1): 108-121.

Kaler, A. (2000). "Who has told you to do this thing?" Signs 25(3): 677-708.

Kaler, A. (2003). Running after pills : politics, gender, and contraception in colonial Zimbabwe. Portsmouth, NH, Heinemann.

Kaler, A. and S. C. Watkins (2001). "Disobedient Distributors: Street-Level Bureaucrats and Would-Be Patrons in Community-Based Family Planning Programs in Rural Kenya." Studies in family planning 32(3 (Sep. 2001)): 254-269.

Kane, T., M. Gueye, et al. (1998). "The Impact of a Family Planning Multimedia Campaign in Bamako, Mali." Studies in Family Planning 29(3): 309-323.

Katz, K. R., C. G. West, et al. (1998). "Increasing Access to Family Planning Services in Community-Based Distribution." International Family Planning Perspectives 24(3): 103 110.

Kirk, D. and B. Pillet (1998). "Fertility Levels, Trends and Differentials in Sub-Saharan Africa in the 1980s and the 1990s." Studies in Family Planning 29.

Kofman, E. (1999). "Female "Birds of Passage" a Decade Later: Gender and Immigration in the European Union." International Migration 33(2): 269-299.

Kulu, H. (2005). "Migration and Fertility: Competing Hypotheses Re-examined." European Journal of Population 21: 51-87.

Lardoux, S. and E. van de Walle (2003). "Polygyny and Fertility in Rural Senegal." Population 58(6): 717-743.

Lee, B. S. (1992). "The Influence of Rural-Urban Migration on Migrant's Fertility in Cameroon." International Migration Review 26(4): 1416-1447. 
Lee, B. S. and L. G. Pol (1993). "The Influence of Rural-Urban Migration on Migrants' Fertility in Korea, Mexico and Cameroon." Population Research and Policy Review 12(1): 3-26. Lesthaeghe, R. (1983). "A century of demographic and cultural change in Western Europe: An exploration of underlying dimensions." Populations Development Review 3: 411-435.

Lesthaeghe, R. (1984).

Lesthaeghe, R. and G. Moors (2000). "Recent Trends in Fertility and Household Formation in the Industrialized World." Review of Population and Social Policy 9: 121-170.

Levitt, P. (1998). "Social Remittances: Migration Driven Local-Level Forms of Cultral Diffusion." International Migration Review 32(4): 926-948.

Lindstrom, D. (2002). "The Short and Long-Term Effects of U.S. Migration Experience on Mexican Women's Fertility." Social Forces 80(4): 1341-1368.

Locoh, T. and M.-P. Thiriat (1995). "Divorce et remariage des femmes en Afrique de l'Ouest. Le Cas du Togo." Population 50(1): 61-93.

Lubkemann, S. C. (2000). "The Transformation of Transnationality among Mozambican Migrants in South Africa." Canadian Journal of African Studies 34: 41-63.

Madhavan, S. (2001). "Female Cooperation and Conflict in Rural Mali: Effects on Infant and Child Survival." Journal of Comparative Family Studies 32(1): 75-98.

Maiga, M. (2006). A genuine reproductive health/family planning experience: "Religious leaders are off to the health center", Health Policy Initiative.

Mason, K. O. (1997). "Explaining Fertility Transitions." Demography 34(4): 443-454.

Mason, K. O. (1997). Gender and demographic change: What do we know? The Continuing Demographic Transition. G. W. e. a. Jones. Oxford, Clarendon Press: 158-182.

Massey, D. (1993). "Theories of International Migration: A Review and Appraisal." Population and Development Review 19(3 (Sep.)): 431-466.

Massey, D. (1999). "International Migration at the Dawn of the Twenty-First Century: The Role of the State." Population and Development Review 25(June): 303-322.

McDonald, P. (2000). "Gender Equity in Theoris of Fertility Transition." Population and Development Review 26(3): 427-439.

McGinn, T. (2000). "Reproductive Health of War-Affected Populations: What Do We Know?" International Famly Planning Perspectives 26(4): 174-180. 
Ministere de la Sante, SERDHA, et al. (1999). Enquete Senegalaise sur les Indicateurs de Sante (ESIS) 1999. Calverton, MD, USA, Ministere de la Sante, Direction des Etudes, de la Recherche et de la Formation, Groupe SERDHA, Services d"Etudes et de Recherche pour le Developpement Humain en Afrique, and Macro Internatinal Inc.,.

Ministry of Health, S. (2006). Description of the Division of Reproductive Health, Ministry of Health, Senegal. 2006.

Mohanty, C. (1988). "Under Western Eyes." Feminist Review 30(Autumn): 61-88.

Morel-Seytoux, S. and H. Lalonde (2002). Gender Assessment and Action Plan for USAID/Rwanda. Washington, D.C., USAID.

Morokvasic, M. (1984). "Birds of Passage are also Women." International Migration Review 18(4, Special Issue: Women in Migration): 886-907.

Muenz, R. (2006). "Europe: Population and Migration in 2005." Migration Information Source. Murphy, K. (2006). France's New Law: Control Immigration Flows, Court the Highly Skilled. Migration Information Source, Migration Policy Institute. 2006.

Ndiaye, S. and M. Ayad (2006). Enquete Demographique et de Sante au Senegal 2005. Calverton, Maryland, USA, Centre de Recherche pour le Developpement Humain [Senegal] et ORC Macro.

Ndiaye, S. and M. Ayad (2006). Enquete Demographique et de Sante, Senegal 2005. Calverton, MD, USA, ORC Macro.

Notestein, F. (1945). Population--The Long View. Food for the World. T. Schultz. Chicago, University of Chicago Press.

Notestein, F. (1953). "Economic Problems of Population Change." Eighth International Conference of Agricultural Economists, London, Oxford University Press.

Office National de la Population and O. Macro (2001). Enquete Demographique et de Sante Rwanda 2000. Kigali, Rwanda et Calverton, MD, U.S.A., Ministere de la Sante, Office National de la Population et ORC Macro.

Ong, A. (1991). "The Gender and Labor Politics of Postmodernity." Annual Review of Anthropology 20: 279-309.

ORC Macro (2004). Cameroon Demographic and Health Survey. Calverton, MD, ORC Macro. ORC Macro (2007). Total Fertility Rate for African Countries, Demographic and Health Surveys' StatMapper 2007, ORC Macro. 2007. 
Parrenas, R. S. (2005). Children of Global Migration: Transnational Families and Gendered Woes. Standford, CA, Standford University Press.

Pedraza, S. (1991). "Women and Migration: The Social Consequences of Gender." Annual Review of Sociology 17: 303-25.

Pessar, P. and S. Mahler (2003). "Transnational Migration: Bringing Gender In." International Migration Review 37(3): 812-846.

Pison, G., A. Gabadinho, et al. (2001). Mlomp, Senegal: Niveaux et Tendance Demographic 1985-2000. Paris, INED.

Quiminal, C. (2000). "Construction des identités en situation migratoire: territoire des hommes, territoire des femmes." Autrepart 14: 107-120.

Quiminal, C. (2002). "Reconstruction des rapports de genre en situation migratoire: femmes reveillees, hommes menace en miliu soninke." VEI Enjeux 128.

Randall, S. and LeGrand (2003). "Reproductive Strategies and Decisions in Senegal: The Role of Child Mortality." Population 58(6): 687-715.

Sargent, C. (2005). "Counseling contraception for Malian migrants in Paris: Global, state, and personal politics." Human Organization 64(2): 147-156.

Sargent, C. and D. Cordell (2003). "Polygamy, disrupted reproduction, and the state: Malian migrants in Paris, France." Social Science \& Medicine 56(9): 1961-1972.

Singley, S. and N. Landale (1998). "Incorporating Origin and Process in Migration-Fertility Frameworks: The Case of Puerto Rican Women." Social Forces 7(4): 1437-70.

Stehpen, E. H. and F. D. Bean (1992). "Assimilation, Disruption and the Fertility of MexicanOrigin Women in the United States." International Migration Review 26(1): 67-88.

Straus, S. (2006). Rwandan refugees. A. Genereux. Madison.

Takyi, B. K. and F. N.-A. Dodoo (2005). "Gender, Lineage and Fertility-Related Outcomes in Ghana." Journal of Marriage and the Family 67(February): 252-257.

Thave, S. (2000). L'emploi des immigres en 1999. Paris, INSEE.

Thompson, W. S. (1929). "Population." American Journal of Sociolgy 34(6): 956-975.

Thomson, E. (1997). "Couple Childbearing Desires, Intentions, and Births." Demography 34(3): 343-354.

Timera, M. (1996). Les Soninke en France. D'une histoire a l'autre. Paris, Karthala. 
Toulemon, L. (2004). "Fertility among immigrant women: new data, a new approach." Population and Societies $\mathbf{4 0 0 .}$

Tsafack, V. N. and P. Calkins (2004). "Roles of migration in the transformation of gender relations in villages of southern Mali." Canadian Journal of Development Studies-Revue Canadienne D Etudes Du Developpement 25(4): 573-589.

Ulin, P. R. (2006). Human Development Rank-Map, United Nations Development Program. 2006.

UNAIDS (2006). Report on the global AIDS epidemic. Geneva, UNAIDS.

UNDP (2006). Human Development Reports: Statistics, United Nations. 2006.

United Nations (2002). HIV/AIDS and Fertility in Sub-Saharan Africa: A Review of the

Research Literature, Population Divsion, Department of Economic and Social Affairs, United Nations Secretariat: 24.

United Nations (2006). International Migration 2006. New York, United Nations, Population Division, Department of Economic and Social Affairs.

United Nations (2006). UN Gender and Migration report. New York, United Nations. Vaa, M. and A. Diallo (2002). Urban Women at the Crossroads of Poverty and New

Responsibilities: A Study of Working Women in Bamako, Mali, International Sociological Association, Brisbane, Australia (ISA).

Van de Kaa, D. J. and R. Lesthaeghe (1986). Two demographic transitions. Population: Growth or Decline. D. J. Van de Kaa and R. Lesthaeghe. Deventer, Van Loghum Slaterus: 9-24. van de Walle, F. and M. Maiga (1991). "Family Planning in Bamako, Mali." International Family Planning Perspectives 17(3).

Vandermeersch, C. and O. Chimere-Dan (2002). "Child Fostering under Six in Senegal in 19921993." Population 57(4/5): 659-685.

Verwimp, P. and J. Van Bavel (2004). Child Survival and the Fertility of Refugees in Rwanda after the Genocide. Sussex, UK, Poverty Research Unit, Department of Economics, University of Sussex.

Watkins, S., J. R. Behrman, et al. (2000). "Empirical Assessments of Social Networks. Fertility and Family Planning Programs: Nonlinearities and their Implications." Demographic $\underline{\text { Research } 1 .}$ 
Watkins, S. and N. Rutenberg (1997). "The Buzz Outside the Clinics: Conversation and Contraception in Nyanza Province, Kenya." Studies in Family Planning 28(4): 290-307.

Watkins, S. C. (1987). "The fertility transition: Europe and the Third World compared." Sociological Forum 2(4): 645-673.

Zamwangana Tungu, J.-P. (2005). Migration Féminine et Fécondité à Kinshasa. Louvain-laNeuve, Academia Bruylant.

Zlotnik, H. (1995). "The South-to-North Migration of Women." International Migration Review 29(1, Special Issue: Diversity and Comparability: International Migrants in Host Countries on Four Continents): 229-254. 


\section{APPENDiX A}

Total Fertility Rate for African Countries,

Demographic and Health Surveys' StatMapper 2007 (ORC Macro 2007)

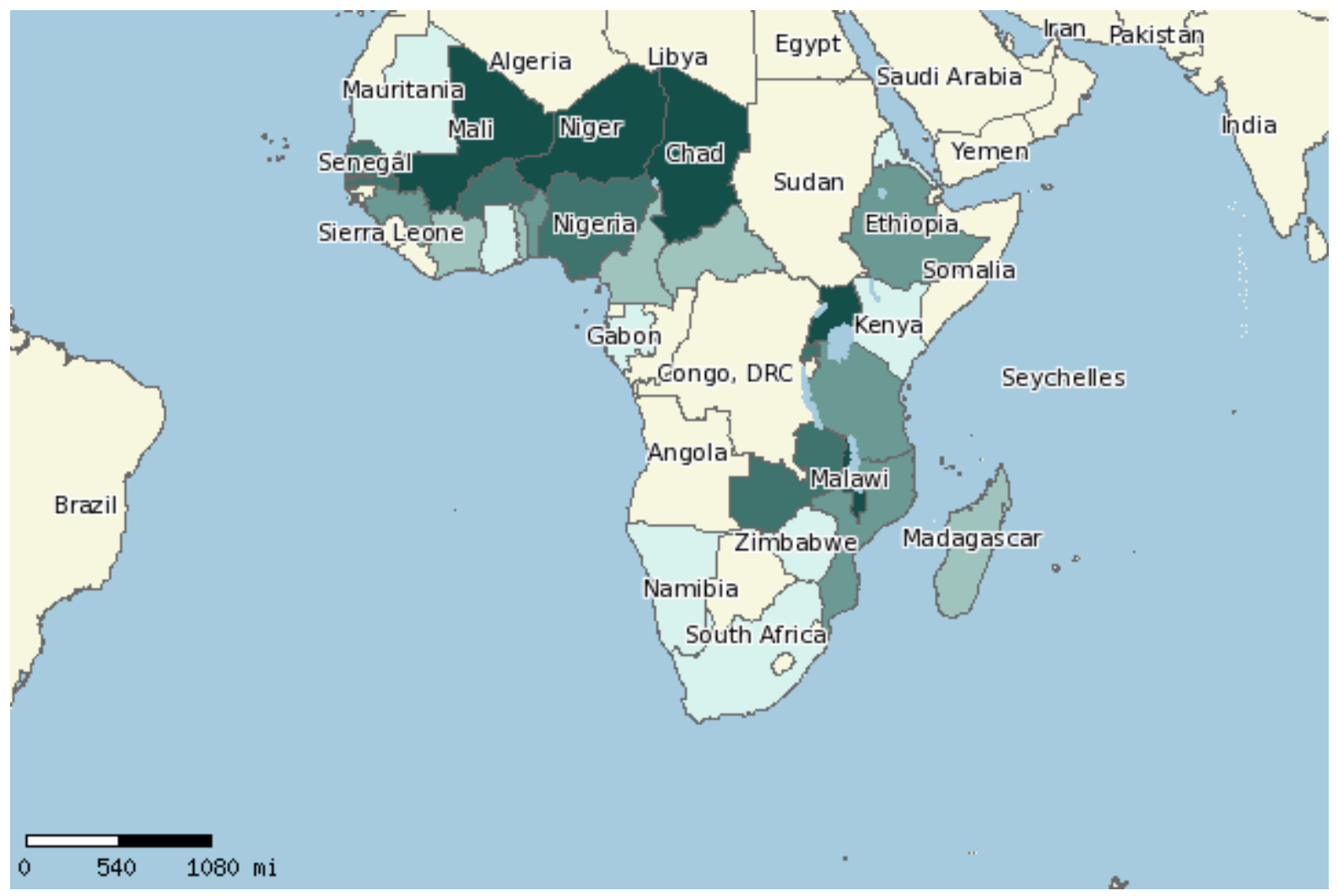

Indicator Quintiles

$6.3-7.2$

$5.7-6.3$

$5.5-5.7$

$5-5.5$

$2.9-5$ 